\title{
Cultivation and Processing of Microalgae for Its Sustainability as a Feedstock for Biodiesel Production
}

\author{
E. O. Ajala ${ }^{1 *}$, M. A. Ajala ${ }^{1}$, G. S. Akinpelu², V. C. Akubude ${ }^{3}$ \\ ${ }^{1}$ Department of Chemical Engineering, University of Ilorin, Ilorin, Nigeria. \\ ${ }^{2}$ Department of Chemical Engineering, Ladoke Akintola University of Technology, Ogbomoso, Nigeria. \\ ${ }^{3}$ Department of Agricultural and Bioresources Engineering, Federal University of Technology, Owerri, \\ Nigeria.
}

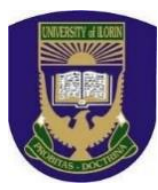

ABSTRACT: Microalgae are becoming sustainable alternative feedstocks to food crops for biodiesel production which can also solve the problems associated with the use of fossil fuels. However, several challenges about microalgae's cultivation, harvesting, pre-treatment and extraction processes as well as the technology of biodiesel production affect its sustainability. This study proffers solutions to these challenges and recommended that hybrid culture systems with genetically engineered microalgal species would overcome the challenges of cultivation. The coagulation/flocculation method was adjudged the best harvesting process of the microalgae for its sustainability for biodiesel production. The pre-treatment by ultrasound coupled with enzymatic extraction was suggested best, due to their numerous advantages over other methods. A novel integrated ultrasound-enzyme-enzyme in-situ pre-treatment-extraction-transesterification design is considered a sustainable approach to utilising microalgae biomass for biodiesel production. The study concludes that the microalgae biomass is more than sufficient to meet the global energy demand and can be economically harnessed as a sustainable feedstock for biodiesel production.

\section{HIGHLIGHTS}

- Microalgae contain sufficient characteristics for their sustainability for biodiesel production.

- Implementation of genetic strategies of microalgal species by cultivating in a hybrid system is the key to microalgae sustainability.

- Harvesting of microalgae by coagulation/flocculation method would promote its efficient lipid recovery.

- Microalgae are novel feedstocks with a rigid cell wall, its lipid extraction requires the use of effective and efficient pretreatment.

- The ultrasound-enzymatic extraction and enzymatic transesterification in an in-situ process can sustainably utilise microalgae biomass for biodiesel production.

KEYWORDS: Microalgae, cultivation, extraction, catalyst, biodiesel.

[Received Jul. 10, 2021; Revised Oct. 9, 2021; Accepted Oct. 20, 2021]

Print ISSN: 0189-9546 | Online ISSN: 2437-2110

\section{INTRODUCTION}

The quest for alternative and sustainable energy resources is gaining worldwide attention due to the depletion of fossil fuel reserves, high energy demands arising from an increase in industrialisation and mechanisation, energy insecurity and environmental degradation (Ajala et al., 2020a; Ibrahim et al., 2020; Ulusoy \& Yu, 2018; Yusuff \& Owolabi, 2019). Biodiesel has been recognised as one of the alternative fuels since it is renewable, environmentally benign and can suffice the ever-increasing demand for energy consumption (Ajala et al., 2020b; Yin et al., 2020). The biodiesel which is also known as a fatty acid methyl esters (FAME) is one of the products of transesterification of oils/fats from vegetable or animal origin and alcohol in the presence of a catalyst (Ajala et al., 2020b). Although vegetable oil/animal fat is renewable, its extensive use can lead to a food crisis as most of the oil/fat used for biodiesel production is from food sources. This informs the efforts aimed at finding alternative lipid-rich biological materials that can overcome the impending food

*Corresponding author: ajala.oe@unilorin.edu.ng shortage crisis that could result due to biodiesel production (Ullah et al., 2014). The lipid-rich material should have short growth cycles and should easily be modified genetically in order to have high lipid content.

Also, researchers are currently looking for ways to reduce the cost of biodiesel production by implementing the use of more viable and cheaper feedstock (Soares et al., 2019). Some microalgae appear to be suitable to meet these criteria and are suggested as potential candidates for biodiesel production $(\mathrm{Xu}$ et al., 2006).

Microalgae are potential and promising feedstocks to building a sustainable bio-based industry as they were estimated to have $200,000-800,000$ species, from among which about 50,000 species have been discovered and researched (Yin et al., 2020). As potential alternative feedstocks for biodiesel production, microalgae do not require arable land for cultivation and so, does not compete with food crop production. They possess a high growth rate and are easy to cultivate in large quantities with high photosynthetic 
efficiency (Alfarisi, 2020). They are simple microscopic autotrophic and/or heterotrophic photosynthetic organisms that can be grouped into either unicellular or multi-cellular forms. These organisms can be cultivated in marine and freshwater habitats. They effectively utilise $\mathrm{CO}_{2}$, light (energy source) and water in a photosynthesis process to synthesise phospholipids, proteins, nucleic acids and carbon-rich lipid (Enamala et al., 2018).

Due to these potential characteristics of microalgae, they can be processed into chemicals (vitamins, pigments and antioxidants), oils (omega-3 fatty acids), animal feed (larval bivalves) and various biofuels such as bio-oil, biodiesel, bioethanol, bio-syngas and bio-hydrogen, based on their species (Yin et al., 2020). These findings suggest that microalgae of various species appear to be the only sustainable, and alternative source of biofuels that have the potential to completely replace fossil fuels. Noteworthy is that many microalgae species are highly rich in lipid and are capable of accumulating many lipids in the cells, and they are suitable for biodiesel production (Kim et al., 2014). Few among the species for biodiesel production are Chlorella sp., Botryococcus braunii, Porphyridium, Nannochlorosis, Neochlorosis, Dunaliella, and Scenedesmus (Rokicka \& Zieli, 2020).

Microalgae are potential sustainable feedstocks for biodiesel production instead of other oil crops as they grow extremely faster. Many of the species have higher energy yield (oil conversion efficiency) per hectare compared to other feedstocks for biodiesel production: Microalgae $(91 \%)>$ oil palm $(3 \%)>$ coconut $(1.5 \%)>$ avocado $(1.4 \%)>$ jatropha $(1.2 \%)>\mathrm{rapeseed} / \mathrm{canola}(1 \%)$ (Yin et al., 2020). This is possible because the microalgae usually multiply their biomass within a day with the oil content exceeding $80 \%$ by weight of dry biomass (Medipally et al., 2015). It was also reported that species of microalgae (Chlorella protothecoides) can accumulate lipids as high as 55\% of the cell dry weight within $144 \mathrm{~h}$ of cultivation (Xu et al., 2006). These suggest that the percentage of oil yield from microalgae could be sufficient to replace transport fuel consumed worldwide. As the United States, for instance, requires only 0.53 billion $\mathrm{m}^{3}$ of biodiesel per annum at the current rate of consumption (Dickinson et al., 2016). Therefore, using lipids from microalgae for biodiesel production is expected to be sustainable. However, Galadima \& Muraza (2014) identified some difficulties hindering microalgae exploitation as a sustainable feedstock, instead of other crops for biodiesel productions.

These are: (1) lack of awareness and knowledge of microalgae prospects, (2) inadequate knowledge of the most cost-effective cultivation process, (3) difficulty in identifying the most suitable microalgae strain that is lipid-rich and with a fast growth rate. Other challenges are; identification of the harvesting process void of wastage, efficient lipid extraction and selection of suitable catalyst for transesterification of microalgae lipid for biodiesel production (Kim et al., 2014). If these challenges are adequately evaluated and fully addressed, microalgae biomass would simply be at the forefront as a sustainable feedstock for biodiesel production (Galadima \& Muraza, 2014). This study appraised the aforementioned challenges facing the sustainability of microalgae feedstocks and proffered necessary solutions. The review concludes that microalgae biomass are sustainable feedstocks for biodiesel production.

\section{PROSPECT AND SUSTAINABILITY OF MICROALGAE FOR BIODIESEL PRODUCTION}

A recent study on global energy consumption based on different sources as shown in Figure 1 reveals that fossil fuel is still the main source of energy demand (Milano et al., 2016). This implies that biodiesel production from first and second generations feedstocks have not been able to meet global energy demands due to several drawbacks. However, microalgae have the potential to overcome the drawbacks associated with the first and second generation feedstocks for biodiesel production. Figure 2 presents oil and biodiesel yields of various feedstocks as reported by Medipally et al. (2015).

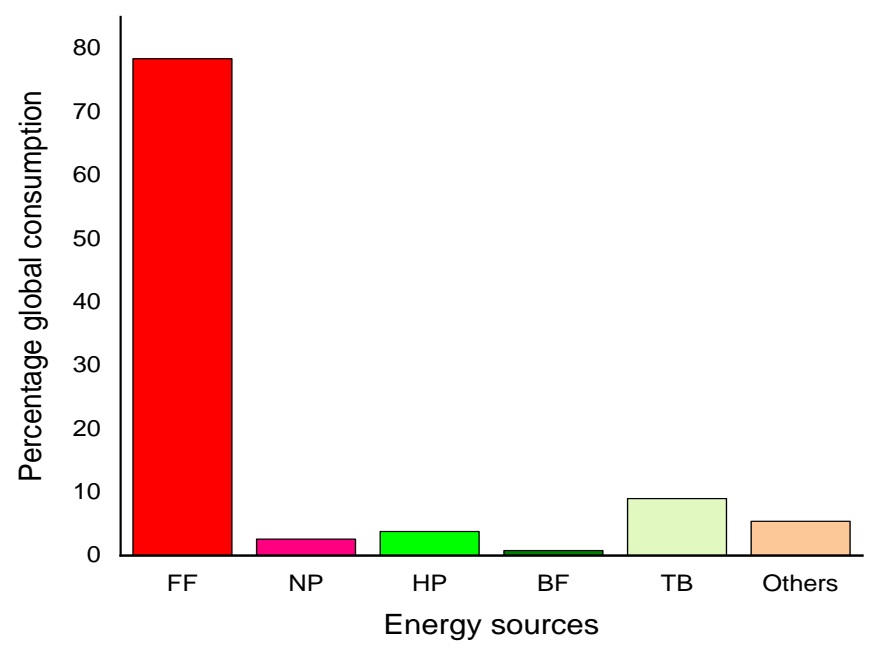

Figure 1: Global Energy Consumption by Source Source: Milano et al. (2016).

Key:- FF - Fossil fuels, $\quad$ BF - Biofuels, NP - Nuclear power, $\mathrm{TB}$ - Traditional biomass, HP - Hydropower.

The figure showed that microalgae of different species based on oil content gave higher yields compared to first-generation and second-generation feedstocks.

Table 1 also presents some prospects of microalgae over first and second generations feedstocks for biodiesel production. These include higher oil yields than terrestrial crops per unit area, land-use change, land-use intensification, and mitigation of greenhouse gas emissions.

Others as identified by Umdu et al. (2009) and Zhang et al. (2014) are microalgae:

- Can grow in freshwater, salty water and wastewaters,

- Possess high growth rates (doubling in $24 \mathrm{~h}$ ) and can be harvested more than once a year,

- Have high lipid content (up to $80 \% \mathrm{w} / \mathrm{w}$ ) as compared to other crops (30\% w/w oil content), 
Table 1: Prospect of microalgae over terrestrial crops for biodiesel production.

\begin{tabular}{|c|c|c|}
\hline Factor & Prospects & References \\
\hline Oil yield & $\begin{array}{l}\text { Microalgae has the highest oil yield of } 136,900 \mathrm{~L} / \mathrm{ha} / \text { year as against rapeseed of } \\
1,190 \mathrm{~L} / \mathrm{ha} / \text { year, oil palm of } 5,950 \mathrm{~L} / \mathrm{ha} / \text { year, corn of } 172 \mathrm{~L} / \mathrm{ha} / \text { year, soybean of } \\
446 \mathrm{~L} / \mathrm{ha} / \text { year, sunflower of } 952 \mathrm{~L} / \mathrm{ha} / \text { year and jatropha of } 1892 \mathrm{~L} / \mathrm{ha} / \text { year. }\end{array}$ & Deng et al. (2009) \\
\hline Land use & $\begin{array}{l}\text { Expanse of land required for microalgae cultivation is much less than that } \\
\text { required for first generation }\end{array}$ & $\begin{array}{l}\text { Mata et al. (2010); Quinn \& } \\
\text { Davis (2015) }\end{array}$ \\
\hline $\begin{array}{l}\text { Over-exploitation of } \\
\text { soil }\end{array}$ & $\begin{array}{l}\text { Cultivation of terrestrial crops for biodiesel production can increase } \\
\text { indiscriminate tillage that leads to soil erosion and affect physical, chemical and } \\
\text { biological properties of soils. Whereas, soils are not directly used for microalgae } \\
\text { cultivation systems. }\end{array}$ & $\begin{array}{l}\text { Correa et al. (2017); Zhu et al. } \\
\text { (2015) }\end{array}$ \\
\hline $\begin{array}{l}\text { Greenhouse } \\
\text { emission }\end{array}$ & $\begin{array}{l}\text { The cultivation of microalgae is expected to alter the magnitude of } \mathrm{CO}_{2} \\
\text { emissions. }\end{array}$ & $\begin{array}{l}\text { Correa et al. (2017); Correa et al. } \\
\text { (2019) }\end{array}$ \\
\hline $\begin{array}{l}\text { Pesticides and } \\
\text { fertilizer pollution }\end{array}$ & $\begin{array}{l}\text { Minimum use of fertilizer and no need of pesticides for microalgae cultivation } \\
\text { compared to terrestrial crops; also, less environmental pollution from } \\
\text { microalgae cultivation. As their use create an increase in heavy metals within } \\
\text { the soil that bio-accumulate inside of the vertebrates animals. }\end{array}$ & $\begin{array}{l}\text { Atafar et al. (2010); Correa et al. } \\
(2017)\end{array}$ \\
\hline
\end{tabular}

- Are non-toxic and highly biodegradable,

- Can yield higher lipid content of between 15-300 times for biodiesel production compared to the traditional crops on an area basis.

These reveal the potentiality of microalgae as a sustainable feedstock for biodiesel production. Therefore, biodiesel from microalgae has attracted much attention due to the low cost of production compared to traditional oils such as vegetable oils, thus it is a sustainable feedstock (Zhang et al., 2014).

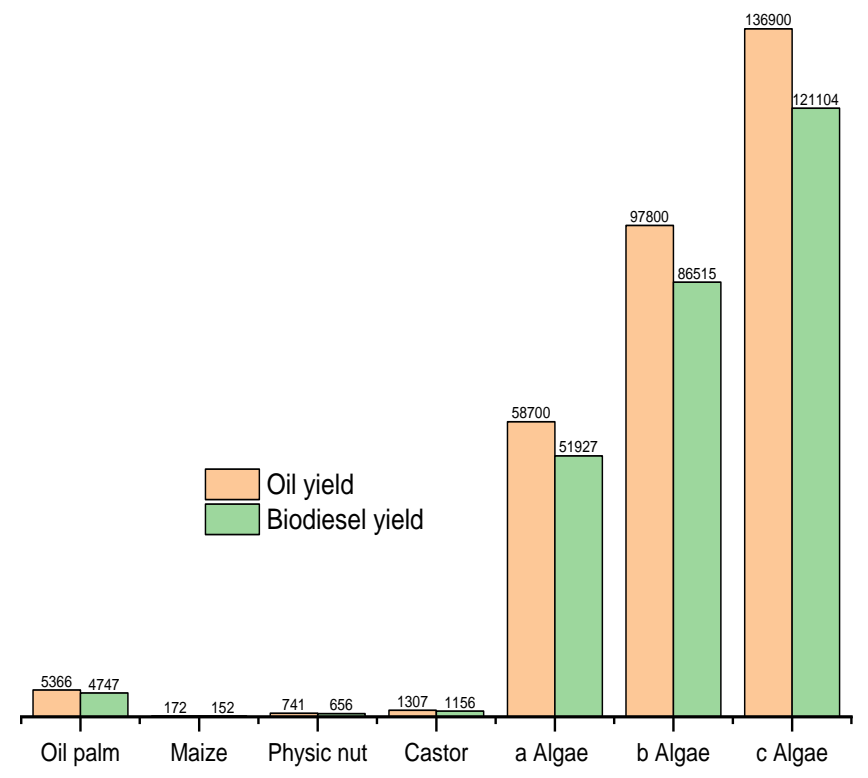

Figure 2: Oil and biodiesel yields of various feedstocks for biodiesel production. Adapted from Medipally et al. (2015).

a Algae - Microalgae with low oil content,

b Algae - Microalgae with medium oil content

c Algae - Microalgae with high oil content

\section{CULTIVATION OF MICROALGAE FOR SUSTAINABLE BIODIESEL PRODUCTION}

The selection of promising species that is rich in lipid and their optimal conditions of cultivation are crucial factors in microalgae sustainability for biodiesel production. Other factors are microalgae adaptation, growth of cultures (inocula), large scale cultivation and the overall reduction of production costs (Cruz et al., 2018). Generally, there are two methods of cultivating microalgae namely; open and closed systems (Shah et al., 2014).

Open culture systems are the oldest and simplest systems for mass cultivation of microalgae (Rakesh et al., 2017). Show et al. (2020) identified some of the advantages of the open pond systems of microalgae cultivation which include low construction cost, low maintenance and operational costs. Other advantages of using open pond systems are simple operation and maintenance, low energy demand and ease to scale up. This system of cultivating microalgae has been regarded as the most cost-efficient cultivation system. However, the open pond systems have some disadvantages; they are limited to a relatively small number of microalgae species and are open to atmospheric influence (Rakesh et al., 2017; Shah et al., 2014). The open culture systems expose microalgae to atmospheric temperature fluctuations and are susceptible to contamination by protozoa and bacteria which results in instability and toxicity of the products (Show et al., 2020). It also leads to substantial loss of water due to evaporation (Shah et al., 2014). The open pond systems also permit rainwater run-off which causes instability in the salinity and $\mathrm{pH}$ of culture medium and affects the growth condition of microalgae. The run-off can lead to erosion of banks of the open pond systems resulting in leakage and increased water turbidity. These can significantly affect the productivity of microalgae, as it is difficult to control some parameters (temperature, dissolved oxygen concentration and light intensity) that influence the growth rate of microalgae (Show et al., 2020).

Contrary to the open culture, closed culture are closed to the atmosphere and require relatively intricate structures, hence have higher construction and operational costs (Shah et al., 2014). Despite the aforementioned relative advantages of open system, a closed system for microalgae cultivation also presents some advantages as highlighted by Geada et al. (2017). As it has better control of $\mathrm{pH}$, temperature, light intensity, $\mathrm{CO}_{2}$ concentration and gas transfer.

Other advantages are a large surface-to-volume ratio, reduced growth medium evaporation, low contamination risk 
and high cell densities. Due to these numerous advantages, the use of a closed system of culturing microalgae is on the increase. It can also eliminate many of the problems associated with the open pond system. However, closed culture systems also have some disadvantages such as variations in light and temperature that can cause sub-optimal growth of microalgae, very high initial capital cost, complexity in design and construction (Rakesh et al., 2017). Figure 3 substantiates that the microalgae biomass production cost is higher for the closed system than the open system, even under different cultivation approaches according to the findings of Slade \& Bauen (2012) and Wang (2013).

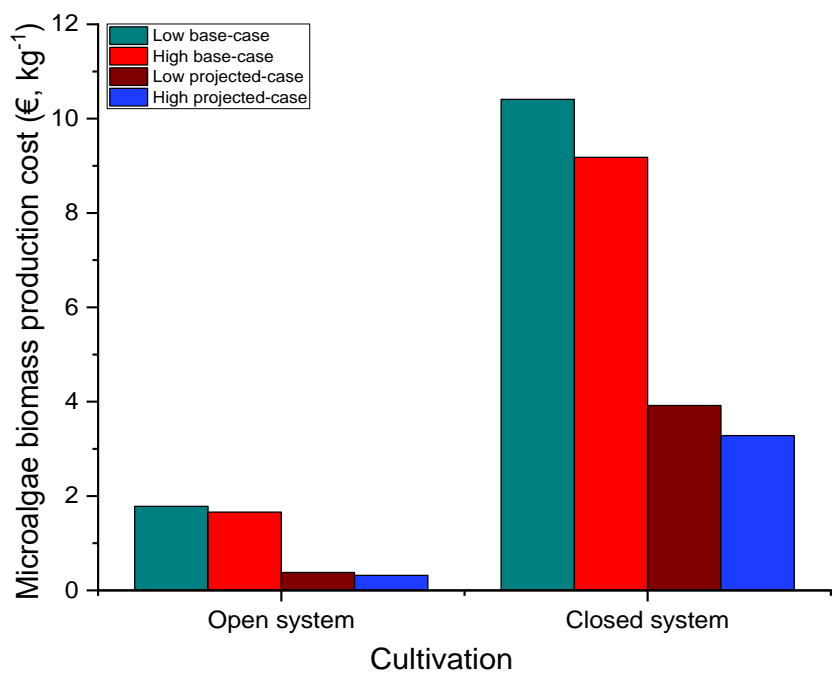

Figure 3: Microalgae biomass production cost by different cultivation systems.

Keys:

Low base-case systems = Cultivation for 300 days using traditional method;

High base-case systems = Cultivation for 360 days using traditional method;
Low projected-case systems $=$ Cultivation for 300 days using new technology;

High projected-case systems $=$ Cultivation for 360 days using new technology.

Since low production cost is a crucial factor in the sustainability of microalgae for biodiesel production, a new effective cultivation method is essential to significantly reduce the cost of large scale production (Wang, 2013). Hence, a more robust culture system that combines the advantages of the open and closed culture systems which is known as a hybrid culture system was suggested by Medipally et al. (2015). In hybrid culture systems, the required amount of contamination-free inocula obtained from a closed system is transferred to open ponds to get maximum biomass yield. Table 2 shows a comparative analysis of the three culture systems of microalgae production.

The hybrid culture system was adjudged the best method as it shows the best performance in terms of growth rate, cultivation season, biomass productivity, nutrient cost, light utilisation, gas transfer, temperature control, set-up cost and contamination risk. Narala et al. (2016) corroborate this claim in their study where biomass productivity was significantly higher for the hybrid cultivation system $\left(14.4\right.$ g.m $\left.\mathrm{m}^{-2} \mathrm{D}^{-1}\right)$ compared to the open $\left(8.8 \mathrm{~g} \cdot \mathrm{m}^{-2} \mathrm{D}^{-1}\right)$ and closed system (13.3 g. $\left.\mathrm{m}^{-2} \mathrm{D}^{-1}\right)$. Similarly, the average growth rate of the hybrid system was significantly higher than those of open and closed systems (Table 2). Therefore, a hybrid culture system could be considered as the best alternative for culturing microalgae for sustainable biodiesel production. In addition to this, genetic modification and metabolic engineering of microalgae would also improve the performance of the hybrid culture system, which would provide the answer to many researchers seeking to overcome the cultivation and harvesting challenges (Geada et al., 2017).

Table 2: Comparative analysis of culturing systems of microalgae production.

\begin{tabular}{|c|c|c|c|}
\hline Factor & Open culture system & Closed culture system & Hybrid culture system \\
\hline Land area & High & Moderate & High \\
\hline Algal species & Limited & Flexible & All species \\
\hline Growth rate $(\mu)$ & 0.10 & 0.11 & 0.18 \\
\hline Volume-to-surface area ratio & $0.25 \mathrm{~m}$ & $0.07 \mathrm{~m}$ & $<0.07 \mathrm{~m}$ \\
\hline Cultivation season (days) & 160 & 300 & 360 \\
\hline Biomass productivity $\left(\mathrm{g} \cdot \mathrm{m}^{-2} \cdot \mathrm{day}^{-1}\right)$ & 10 & 20 & $>20$ \\
\hline Nutrient cost $\left(£ . \mathrm{kg}^{-1}\right)$ & 0.4 & 0.4 & $<0.4$ \\
\hline Control of growth parameters & Difficult & Easy & Excellent \\
\hline Water evaporation $\left(\mathrm{L} \cdot \mathrm{m}^{-2} \cdot \mathrm{day}^{-1}\right)$ & 10 & 0.5 & Between 0.5 and 10 \\
\hline Light utilisation efficiency & Poor & Fair & Excellent \\
\hline Gas transfer & Poor & Low & High \\
\hline Temperature & Unstable & Relatively stable & Perfectly stable \\
\hline Temperature control & None & Good & Excellent \\
\hline Setup cost & Low & High & Moderate \\
\hline Contamination risk & High & Low & Low \\
\hline Maintenance & Easy & Difficult & Moderate \\
\hline The energy input for mixing & Low & High & Moderate \\
\hline
\end{tabular}

Sources: Medipally et al. (2015); Narala et al. (2016); Slade \& Bauen (2012). 
Genetic modification of microalgae species is another crucial step in its mass cultivation for biodiesel production. Although the application of genetic engineering in the cultivation of microalgae for biodiesel production is presently at the preliminary stage, efforts are ongoing on the development of genetic transformation strategies. The strategies are sequencing of nuclear and mitochondrial, physical cell separation process follows (Branyikova et al., 2018).

Other challenges associated with this process are; difficulty in extracting the bio-oil from their intracellular site in a cost-effective approach, optimum use of energy and circumventing the use of a high quantity of solvent (such as nhexane) (Bhatt et al., 2014). Therefore, efforts should be made

Table 3: Cost analysis of various harvesting methods.

\begin{tabular}{|c|c|c|c|c|c|}
\hline Harvesting method & Capital cost $\left(\$ \mathrm{~m}^{-3}\right)$ & $\begin{array}{l}\text { Operational } \\
\text { cost }\left(\$ \mathrm{~m}^{-3}\right)\end{array}$ & $\begin{array}{l}\text { Energy consumption } \\
\left(\mathrm{kWh} \mathrm{m}^{-3}\right)\end{array}$ & $\begin{array}{l}\text { Energy cost } \\
\left(\$ \text { m }^{-3} \text { year }^{-1}\right)\end{array}$ & $\begin{array}{l}\text { Total cost }\left(\$ \mathrm{~m}^{-3} \text { per } 1 \text { year }\right. \\
\text { of operation })\end{array}$ \\
\hline Sedimentation & 0.03 & $0.05-0.39$ & $0.05-0.1$ & $49.10-98.21$ & $49.23-98.73$ \\
\hline Coagulation/flocculation & 0.03 & $0.06-1.5$ & $0.02-0.2$ & $19.64-196.42$ & $19.75-198.15$ \\
\hline Inorganic flocculation & 0.36 & $0.53-2.26$ & $0.00084-2.85$ & $0.83-2798.93$ & $1.72-2804.40$ \\
\hline Organic flocculation & 0.26 & $0.1-21.45$ & $0.1-14.81$ & $98.21-14544.61$ & $98.67-14581.12$ \\
\hline Electrolytic flocculation & $0.05-6.03$ & $0.11-1.45$ & $0.04-9.5$ & $39.28-9329.76$ & $39.48-9346.74$ \\
\hline Magnetic flocculation & 1.02 & 0.62 & 6.5 & 6383.52 & 6391.66 \\
\hline Hydro cyclone & 4.32 & 1.87 & 0.3 & 294.62 & 301.11 \\
\hline Dissolved air flotation & 1.46 & $0.26-1.80$ & $0.6-20$ & $589.25-19641.60$ & $591.57-19664.86$ \\
\hline Electrolytic flotation & 1.07 & 0.65 & $0.3-2$ & $294.62-1964.16$ & $296.64-1967.88$ \\
\hline Suspended air flotation & 1.04 & 0.65 & $0.003-0.015$ & $2.95-14.73$ & $4.64-16.44$ \\
\hline Micro strainer filtering & 0.05 & 0.02 & $0.02-0.5$ & $19.64-491.04$ & $19.73-491.61$ \\
\hline Acoustic aggregation & 2.6 & 0.65 & $16-40$ & $15713.28-39283.2$ & $15732.53-39326.45$ \\
\hline
\end{tabular}

Adapted and modified from Deconinck et al. (2018); Note: The world average price of electricity for business users $=\overline{\$ 0.124}$ per $\mathrm{kWh}$.

chloroplast genomes and creation of expressed sequence tag (EST) databases (Medipally et al., 2015). The existing molecular strategies essential to advance microalgae cultivation for biodiesel production consist of; blocking metabolic pathways that give energy-rich compounds (starch and cellulose), declining lipid catabolism which involves removal of fatty acid $\beta$-oxidation that consumes triacylglycerides, alteration of lipid characteristics, direct biological synthesis of fatty acids, secretion of triacylglycerides and free fatty acids (Radakovits et al., 2010). These strategies are not yet fully implemented which is affecting the sustainability of microalgae for biodiesel production.

Although cultivation had been regarded as the main cost contributor for microalgae-based products, the harvesting and dewatering process is another important contributor to the total costs (Fasaei et al., 2018). Several studies have reported that harvesting is a critical step in the production process of microalgae, accounting for about 20 to $30 \%$ of the total production cost due to high energy demand and capital cost (Fasaei et al., 2018; Pacheco et al., 2015; Roy, 2017; Show et al., 2020). Hence, the harvesting process is an important factor in the sustainability of microalgae for biodiesel production.

\section{HARVESTING-DEWATERING PROCESS OF MICROALGAE}

Harvesting is the next process after cultivation; however, a high volume of microalgae suspension usually accompanies the process which requires significant reduction. Hence, a two-stage process is usually followed which are harvesting and dewatering, to achieve a cost-effective downstream processing (Branyikova et al., 2018).

The process is challenging due to the small size and low density of microalgae which increase the capital cost (Shah et al., 2014) but a low-cost technique can be applied at the initial stage before the energy-consuming and capital intensive to justify the choice of unit operation that can overcome the challenges for harvesting and dewatering processes.

The cost implications of using various harvesting methods for microalgae over one year were evaluated as shown in Table 3. From the table, the suspended air flotation has the lowest cost, ranges from $\$ 4.64$ to $\$ 16.44$, followed by sedimentation (\$49.23 - \$98.73) and coagulation/flocculation (\$19.75 - \$198.15), the highest being the acoustic aggregation method with the cost ranges from $\$ 15,732.53$ to $\$ 39,326.45$ (Deconinck et al., 2018). However, the cost-effectiveness alone cannot justify the recommendation of the best harvesting method for microalgae as each has its advantages and disadvantages (Branyikova et al., 2018). Table 4 presents the result of the analysis based on the advantages and disadvantages of performance factors of some microalgae harvesting methods. The analysis shows that the coagulation/flocculation method has the highest rating (10/13) ahead of the sedimentation method with a rating of 9/13. Hence, comparing the total cost and performance factors of the various methods of microalgae harvesting for biodiesel production, the coagulation/flocculation method can be recommended as the best. This is because of its many advantages, especially its short operational time and suitability to handle all species of microalgae.

Also, the low operational cost with high cell recovery of $>90 \%$ by the coagulation/flocculation method indicates a reduction in the harvesting costs. This is considered a crucial factor for the sustainable and inexpensive production of biodiesel (Mathimani \& Mallick, 2020). The suitability of the coagulation/flocculation method of microalgae harvesting for sustainable biodiesel production was corroborated by Singh \& Patidar (2018). This method has been regarded as a promising technique that could substantially improve the operation and 
Table 4: Performance analysis of microalgae harvesting methods for sustainable biodiesel production. Performance Factors

\begin{tabular}{|c|c|c|c|c|c|c|c|c|c|c|c|c|c|c|}
\hline Method & 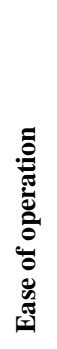 & 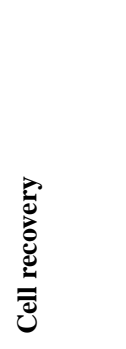 & 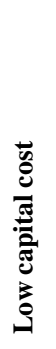 & 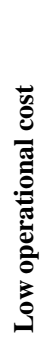 & 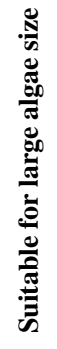 & 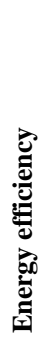 & 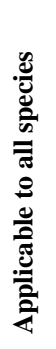 & 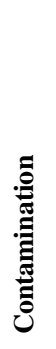 & 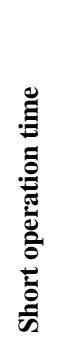 & 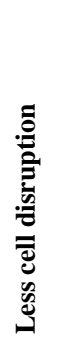 & 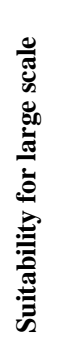 & 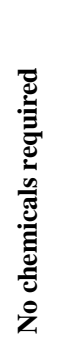 & 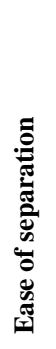 & 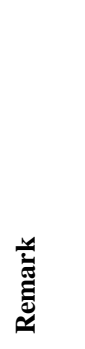 \\
\hline Coagulation/flocculation & + & $>90 \%$ & - & + & + & + & + & - & + & + & + & - & + & $10 / 13$ \\
\hline Sedimentation & + & $10-90 \%$ & + & + & + & + & - & + & - & + & - & + & - & 9/13 \\
\hline Centrifugation & + & $>90 \%$ & - & - & - & - & + & + & + & - & - & + & + & $7 / 13$ \\
\hline Filtration & - & $70-90 \%$ & - & 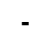 & + & + & 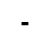 & + & + & + & - & + & - & $7 / 13$ \\
\hline Flotation & + & $50-90 \%$ & - & + & - & - & + & + & + & + & + & - & - & 8/13 \\
\hline Electrical based processes & + & $>90 \%$ & . & & - & . & + & 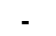 & + & & + & + & + & $6 / 13$ \\
\hline
\end{tabular}

Adapted from Branyikova et al. (2018); Fasaei et al. (2018); Singh \& Patidar, (2018).

Note that each item of performance factors was rated 1 point with the total equals 13; Each method was rated based on total performance of 13 as shown

economic balance of harvesting microalgae for biodiesel production (Branyikova et al., 2018).

Figure 4 shows the economic appraisal of various methods of dewatering after the harvesting of microalgae as reported by Al hattab et al. (2015). The analysis suggests that the disc stack centrifuge has the highest efficiency of $87 \%$ among other methods. The disc stack centrifuge can be coupled with the coagulation/flocculation method of harvesting to optimally recover microalgae biomass for the extraction process of lipid.

Therefore, the sustainability of microalgae as a feedstock for biodiesel production must consider some variables such as specie selection, genetic engineering of selected species, cultivation strategy, costs, nutrients supply, harvesting and dewatering strategy implementation and final products' concentration, to attain high-productivity of microalgae growth and lipid yield in a cost-effective way (Geada et al., 2017).

\section{EXTRACTION OF LIPID FROM MICROALGAE}

The efficient production of biodiesel from microalgae depends on some factors which include optimum lipid recovery through an extraction process. The lipid extraction from microalgae cells is difficult as some lipids are bound to the cell membranes. The pre-treatment of microalgae biomass before the extraction process is required to break the cells and rupture the cell walls to efficiently recover the lipid (Rokicka $\&$ Zieli, 2020). This is due to the presence of a thick and robust cell wall structure that prevents the release of intracellular lipid (Jegan et al., 2014). The breaking of the cell structure before the extraction is beneficial to the process as it reduces extraction time, low solvent consumption, greater solvent penetration into the cell and increasing release of the cell content (Rokicka \& Zieli, 2020). Several pre-treatment methods for effective microalgae cell disruption were reported in the literature such as homogeniser, bead mill, ultrasound, autoclaving, freezing and osmotic shock (Taher et al., 2011).
However, according to the literature, the most promising method for cell disintegration of microalgae is the use of ultrasounds (Rokicka \& Zieli, 2020). This is due to the nature of rigid cell wall of microalgae, therefore, their lipid extraction require the use of an effective and efficient pre-treatment method to attain its sustainability for biodiesel production (Mubarak \& Shaija, 2016).

Naveena et al. (2015) reported several advantages of the ultrasound pre-treatment method of microalgae: (1) The physical effects of ultrasonication enhance the transesterification process during biodiesel production, (2) It allows the rapid selective extraction of specific biomass components and can enhance product yield which can be of economic benefit, (3) It promotes the enzymatic reactions within the cell for extraction and transesterification, (4) It effectively improves the extraction rate by increasing the mass transfer due to the formation of microcavities leading to higher growth and product yield, (5) It can also facilitate the swelling and hydration of biomass which leads to pores enlargement within the cell wall and improve diffusion processes, thereby enhance mass transfer and promote extraction yield. Hence, ultrasound can provide high extraction efficiency in a short time with less solvent consumption over other extraction techniques.

Mubarak \& Shaija (2016) obtained a sequence of yields with various pre-treatment methods which were preceded by Bligh and Dyer's method of extraction for Salvinia molesta (aquatic weed). It was reported that the lipid yield was 19.97\% $(\mathrm{w} / \mathrm{w})$ for ultrasound $>16.60 \%(\mathrm{w} / \mathrm{w})$ for microwave > $16.46 \%(\mathrm{w} / \mathrm{w})$ for glass grinding $>16.26 \%(\mathrm{w} / \mathrm{w})$ for sand grinding $>15.72 \%(\mathrm{w} / \mathrm{w})$ for autoclave $>15.36 \%(\mathrm{w} / \mathrm{w})$ for untreated microalgae. The finding concluded that the ultrasound method of pre-treatment was the most efficient with the highest lipid yield among all the methods reported. Table 5 shows the efficiency of the pre-treatment process visà-vis the extraction process on the total oil yield from different 


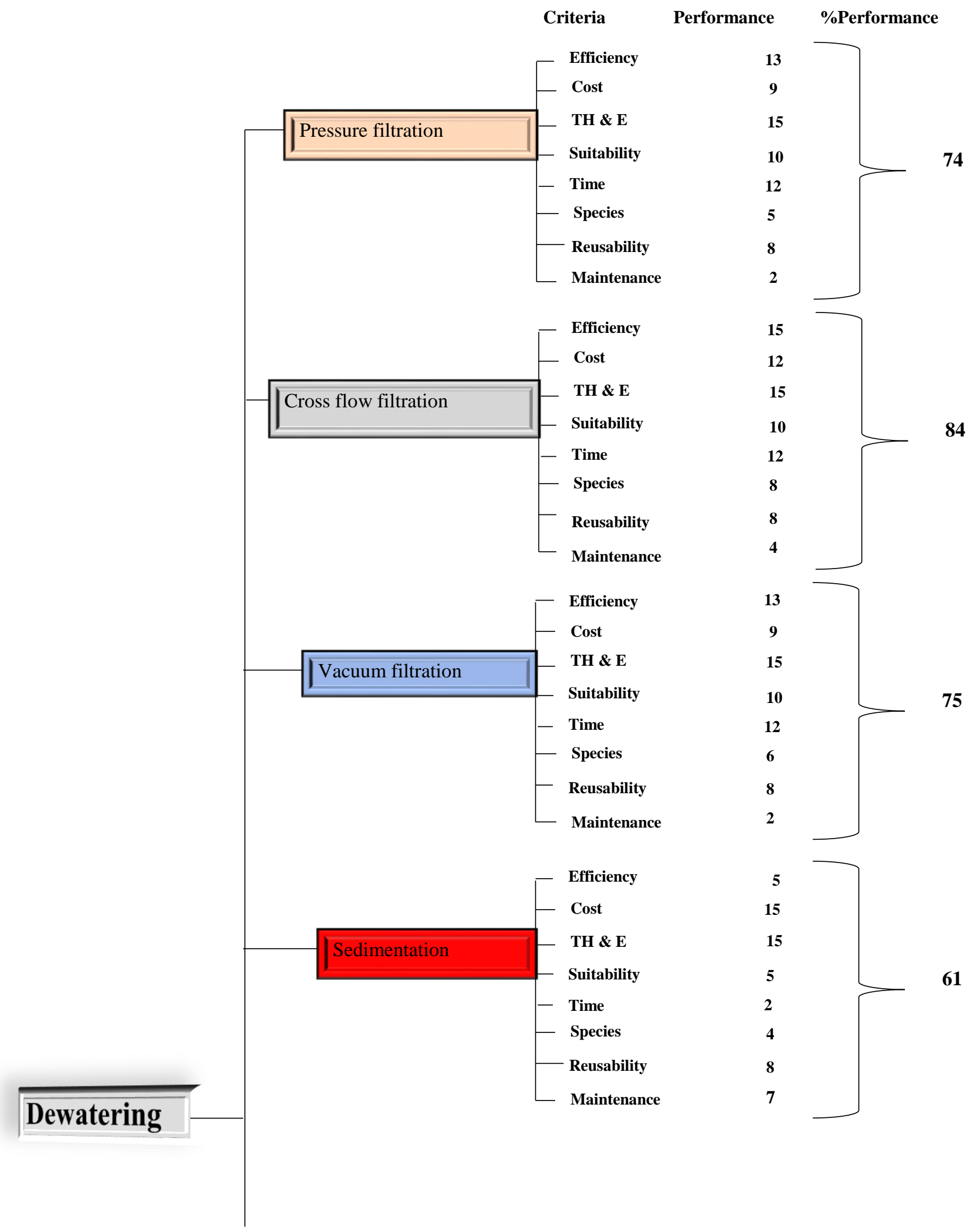

Figure 4: Economical analysis of different dewatering processes. 


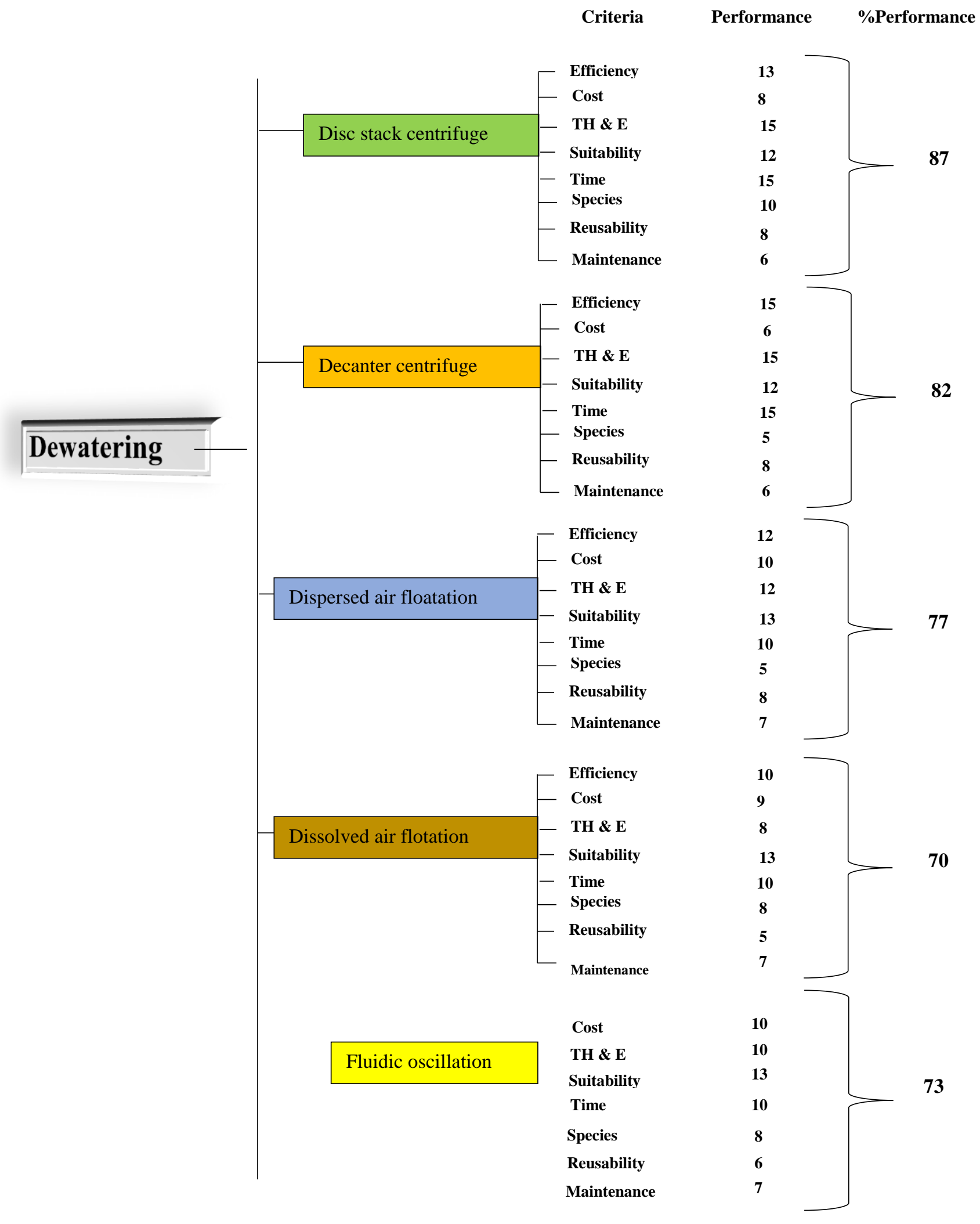

Figure 4 Continued. 


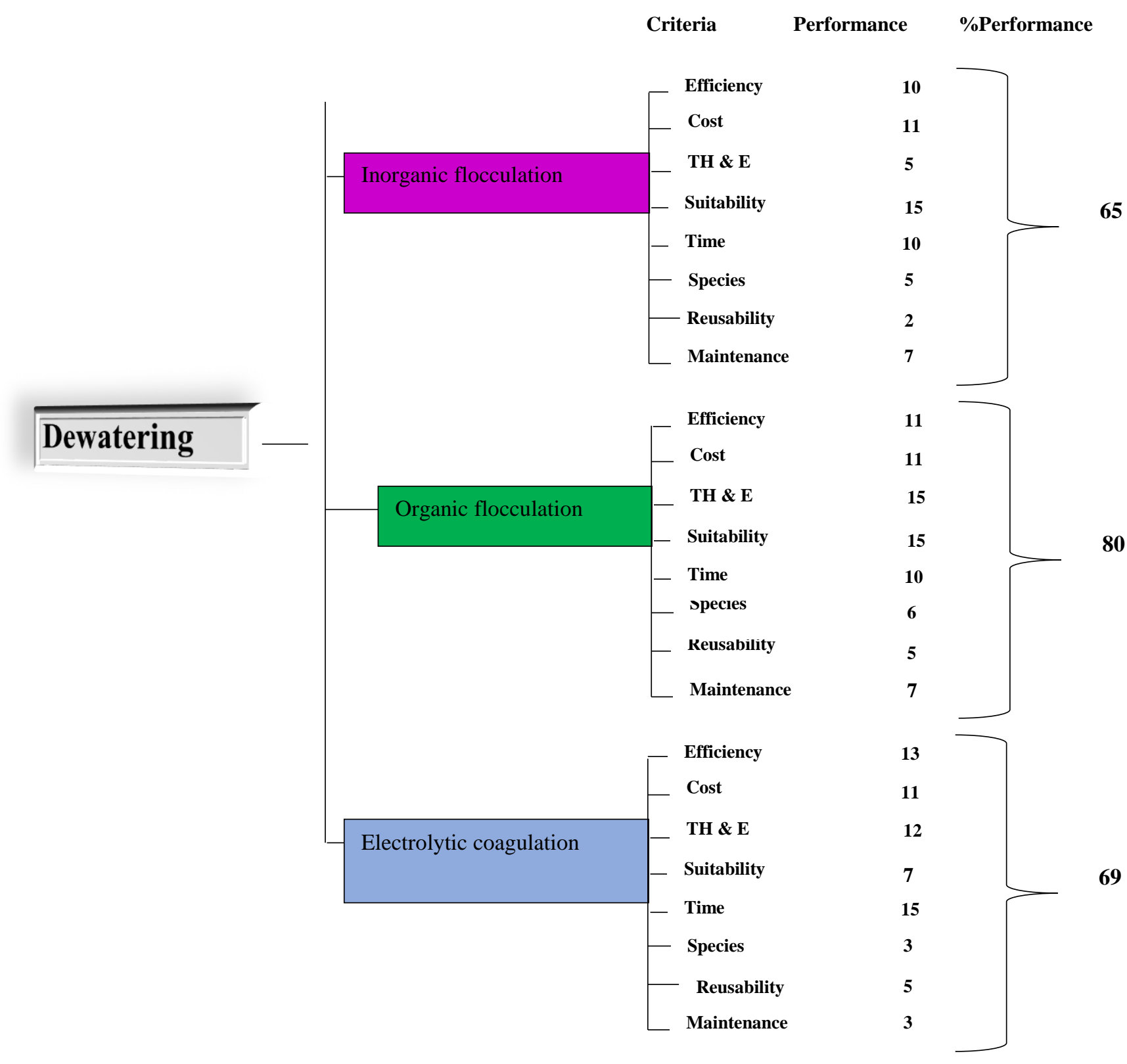

Figure 4 Continued.

Key:

Criteria for economic analysis of

harvesting method

Efficiency (Dewatering)

Cost

Toxicity, health, and environmental impact (TH \& E)

Suitability (For large scale use)

Time

Species (Specificity)

Reusability (of media)

Maintenance
Description

Effective concentration and extent of percentage removal of the cells from their surrounding liquid media

Low operational costs reduce the total processing cost.

Note: The lower the operational cost the higher the grade

Easy handling and environmental friendliness of the process is crucial to the sustainability of microalgae for biodiesel production

Efficiency in handling huge volumes for industrial scale is essential

Quick harvesting duration would reduce operational cost and ensure sustainability

Non-selective of species or strain

Recycle of media in the operation reduce costs

Low maintenance cost is encouraged
65

80

69

Performance rating 
species of microalgae. Evaluating the percentage yields of oil from Scenedesmus sp. of microalgae species reported by Cho et al. (2012); González-gonzález et al. (2019) and Patel et al. (2018) revealed that the enzymatic pre-treatment gave high yields of $73.0,78.7$ and $86.4 \%$ when solvent extraction was employed. Comparatively, other pre-treatment methods yielded a lower oil recovery of 24.9. 19.8, 32.0 and $47.4 \%$ even after solvent extraction (Table 5).

\begin{tabular}{|c|c|c|c|c|c|}
\hline $\mathbf{S} / \mathbf{N}$ & Microalgae species & Pre-treatment & Extraction & \%Oil yield & References \\
\hline \multirow[t]{7}{*}{1} & Scenedesmus sp. & Homogenization & Chloroform: $\mathrm{MeOH}$ & 24.9 & Cho et al. (2012) \\
\hline & & - & Chloroform: $\mathrm{MeOH}$ & 19.8 & \\
\hline & & Enzymatic (Cellulase) & Hexane & 73.0 & González-gonzález et al. (2019) \\
\hline & & Enzymatic (Lysozyme) & Hexane & 78.7 & \\
\hline & & Surfactant & Hexane: Isopropanol & 32.0 & \\
\hline & & Lyophilized & Sulphuric acid & 47.4 & \\
\hline & & $\begin{array}{l}\text { Enzymatic (Cellulase, } \\
\text { xylanase and pectinase) }\end{array}$ & Chloroform: $\mathrm{MeOH}$ & 86.4 & Patel et al. (2018) \\
\hline \multirow[t]{6}{*}{2} & Nannochloropsis oculata & Acid & Bligh and dyer & 33.18 & Surendhiran \& Vijay (2014) \\
\hline & & Ultrasound & & 30.12 & \\
\hline & & Autoclave & & 28.06 & \\
\hline & & Enzymatic & & 32.74 & \\
\hline & & Microwave & & 26.51 & \\
\hline & & $\mathrm{NaCl}$ & & 26.45 & \\
\hline \multirow[t]{6}{*}{3} & Chlorella vulgaris & Microwave & Chloroform: $\mathrm{MeOH}$ & 10.0 & Dvoretsky et al. (2016) \\
\hline & & Ultrasound & Chloroform: $\mathrm{MeOH}$ & 52.0 & \\
\hline & & Ultrasound & Enzymatic & 49.82 & González-gonzález et al. (2019) \\
\hline & & Ultrasound & Bligh and dyer & 8.8 & Prabakaran \& Ravindran (2011) \\
\hline & & Enzymatic (Cellulase) & Chloroform: $\mathrm{MeOH}$ & 10 & Dvoretsky et al. (2016) \\
\hline & & Autoclave & & 24 & \\
\hline \multirow[t]{4}{*}{4} & Nannochloropsis sp. & - & Subcritical hexane-ethanol & 88.2 & González-gonzález et al. (2019) \\
\hline & & Weak alkali & $\begin{array}{l}\text { Enzymatic (cellulase and } \\
\text { lysozyme) }\end{array}$ & 22.18 & Chen et al. (2017) \\
\hline & & Enzymatic & Hexane: Propanol & 37.3 & Dvoretsky et al. (2016) \\
\hline & & Ultrasound & Enzymatic & 11.7 & González-gonzález et al. (2019) \\
\hline \multirow[t]{6}{*}{5} & Chlorella protothecoides & - & Chloroform: $\mathrm{MeOH}$ & 9.34 & Piasecka et al. (2014) \\
\hline & & & Hexane: $\mathrm{MeOH}$ & 3.94 & \\
\hline & & Microwaves & Chloroform: $\mathrm{MeOH}$ & 21.39 & \\
\hline & & & Hexane: $\mathrm{MeOH}$ & 17.92 & \\
\hline & & Ultrasound & Chloroform: $\mathrm{MeOH}$ & 42.00 & \\
\hline & & & Hexane: $\mathrm{MeOH}$ & 41.43 & \\
\hline \multirow[t]{4}{*}{6} & $\begin{array}{l}\text { Rhodosporidium } \\
\text { kratochvilovae }\end{array}$ & Ultrasound & Bligh and dyer & 59.7 & Patel et al. (2018) \\
\hline & & Acidic & Hexane & 61.9 & \\
\hline & & Microwave & & 67.4 & \\
\hline & & Ultrasound-microwave & & 70.1 & \\
\hline \multirow[t]{3}{*}{7} & Chlorella sp. & Microwave & Chloroform: $\mathrm{MeOH}$ & 38 & Prabakaran \& Ravindran (2011) \\
\hline & & Autoclave & & 24 & \\
\hline & & Ultrasound & & 40 & \\
\hline
\end{tabular}

A similar trend of higher yield was also reported by Surendhiran \& Vijay (2014) for enzymatic pre-treatment of Nannochloropsis oculate (32.74\%) compared to other pretreatment methods \{ultrasound (30.12\%), autoclave (28.06\%), microwave $(26.51 \%)\}$. Although, acid pretreatment gave a little higher yield of $33.18 \%$ compared to the enzymatic pretreatment $(32.74 \%)$. This may be due to other factors such as enzyme type, operating conditions, and microalgae species. However, when the enzyme was used to pre-treat Chlorella vulgaris, a lower yield of $10 \%$ was attained compared to
$52.0 \%$ and $49.82 \%$ (ultrasound) and $24 \%$ (autoclave) for the pre-treatment methods (Dvoretsky et al., 2016; Gonzálezgonzález et al., 2019). These findings suggest that the choice of an efficient pre-treatment method for the extraction of lipid may also depend on the species of microalgae, which was corroborated by Silva et al. (2014). Efficient lipid extraction and highest oil recovery remain the major downstream processing challenges in the utilisation of microalgae as a sustainable feedstock for biodiesel production (Kumar et al., 2015). 
Typical procedures of lipid extraction from microalgae are mechanical, solvent ( $\mathrm{n}$-hexane, chloroform, methanol, and propanol), ultrasonic, enzymatic, and supercritical (water, methanol and $\mathrm{CO}_{2}$ ) methods. Figure 5 shows extraction methods with their efficiencies and relative challenges that must be overcome for efficient lipid extraction of microalgae based on the findings of Kumar et al. (2015). This is crucial for the sustainability of microalgae as a cheap feedstock for biodiesel production. It was observed from the figure that the enzymatic method was adjudged to have a very high yield of oil recovery, followed by supercritical and pressurised solvent (high yield), solvent and bead beating (moderate yield) and mechanical method (low moderate yield) (Kumar et al., 2015). Comparative higher efficiency of enzymatic extraction $(49.82 \%)$ to other methods (Bligh and dyer, $8.8 \%$; solvent, 10 and 24\%) was also corroborated by González-gonzález et al. (2019) when extracting Chlorella vulgaris. This suggests that enzymes could easily rupture the wall of the microalgae for the efficient release of lipid.

However, contrasting observations were reported by Chen et al. (2017); Dvoretsky et al. (2016) and Gonzálezgonzález et al. (2019) as presented in Table 5, when lipid was extracted from Nannochloropsis $s p$. of microalgae. From the table, a high yield of $88.2 \%$ was obtained when the subcritical hexane-ethanol solvent extraction method was employed. Regardless of the pre-treatment methods, the table shows that the enzymatic extraction gave lower lipid yields of 11.7 and $22.18 \%$ compared to the $88.2 \%$ of solvent extraction. It was also revealed that solvent extraction using $\mathrm{n}$-hexane and propanol gave a lipid yield of $37.3 \%$, a value higher than that of the enzymatic extraction method (11.7\%). This shows that the subcritical solvent extraction method could be considered as the most efficient for extracting lipids from Nannochloropsis sp. This difference in the efficiency of enzymatic extraction as reported by González-gonzález et al. (2019) and Chen et al. (2017) could be attributed to the species of microalgae, enzyme type and the temperature of extraction.

Furthermore, other procedures of extraction such as the mechanical method could be simple to use with lower capital cost. However, the oil recovery yield is very low with attendant high-power consumption and maintenance cost. The mechanical method, though environment-friendly, has the problem of a possible degradation of lipid due to high temperature (Kumar et al., 2015). Although solvent extraction is the most widely used due to its high extraction capability and low cost, it is time-consuming, has an inherent hazard to human and environmental health, particularly when a less polar solvent is employed (Dickinson et al., 2016). Ultrasonic method was also found to be efficient and fast for microalgae lipid extraction, but requires a large volume of solvent, especially when microalgae biomass concentration is low (Taher et al., 2011).

Supercritical $\mathrm{CO}_{2}$ extraction method has numerous advantages over solvent extraction which includes nontoxicity and non-oxidizing environment that can degrade lipid extracts; low critical temperature (around $31^{\circ} \mathrm{C}$ ) that prevents thermal degradation of products; high diffusivity and low surface tension that permit penetration in pores smaller than those accessible by chemical solvents and easy separation of
$\mathrm{CO}_{2}$ at ambient temperature after extraction. But, the cost of operation and capital investment, complexity of operation and safety-related issues are the main challenges of its deployment in microalgae lipid extraction for biodiesel production (Jegan et al., 2014). In addition, most of the extraction methods identified operate at a laboratory scale which is difficult to scale up to industrial production of lipid, due to volume and complexity.

Therefore, a more promising way for effective and efficient lipid extraction of microalgae could be a combination of enzymatic method with other methods of pre-treatment (Kumar et al., 2015). The pre-treatment by ultrasound coupled with enzymatic extraction would be the easiest, economical and efficient method for microalgae lipid extraction (Prabakaran \& Ravindran, 2011). On a general note, the selection of the pretreatment-extraction procedure for the efficient lipid extraction of microalgae does not only depend on the procedure adopted but also on the microalgae species and other process conditions (Silva et al., 2014). So, a suitable pretreatment-extraction procedure is crucial to attaining microalgae sustainability for biodiesel production.

\section{CATALYST TYPES FOR THE SUSTAINABILITY OF LIPID MICROALGAE FOR BIODIESEL PRODUCTION}

Microalgae sustainability for biodiesel production also depends on the choice of the most appropriate catalyst and reaction conditions for the transesterification process. These have posed a great challenge to the use of microalgae lipid in biodiesel industries. Chemical catalysts (acid/base) and biocatalysts have been reported for biodiesel production from microalgae lipid (He et al., 2018). The chemical catalysts such as homogeneous and heterogeneous catalysts were usually adopted for the transesterification of microalgae lipid (Du et al., 2018).

The homogeneous catalysts, acid $\left(\mathrm{H}_{2} \mathrm{SO}_{4} ; \mathrm{H}_{3} \mathrm{PO}_{4} ; \mathrm{HCl}\right.$, $\left.\mathrm{HNO}_{3}\right)$ and base $\left(\mathrm{NaOH}, \mathrm{KOH}, \mathrm{KOCH}_{3}, \mathrm{NaOCH}_{3}, \mathrm{Mg}(\mathrm{OH})_{2}\right)$ have been reported to give higher yields of biodiesel from microalgae lipids as shown in Table 6. Kim et al. (2015) investigated the use of acid catalysts $\left(\mathrm{HCl}\right.$ and $\left.\mathrm{H}_{2} \mathrm{SO}_{4}\right)$ in direct transesterification of wet microalgae (Nannochloropsis Gaditana) and obtained a $90 \%$ yield of biodiesel with $\mathrm{HCl}$. The $\mathrm{HCl}$ yielded $15 \%$ more biodiesel than $\mathrm{H}_{2} \mathrm{SO}_{4}$ that yielded $75 \%$ under the same process conditions. It was stated that $\mathrm{HCl}$ has a better performance than the $\mathrm{H}_{2} \mathrm{SO}_{4}$ because of the effect of moisture content which requires more quantity of catalyst and solvent for efficient transesterification. In another study of $\mathrm{HCl}$ and $\mathrm{H}_{2} \mathrm{SO}_{4}$ as acid catalysts on the transesterification of microalgae (Coelastrella sp.), the influence of the methyl group was found to affect the yield of biodiesel. The $\mathrm{H}_{2} \mathrm{SO}_{4}$ yielded $1.23 \%$, which is higher than the $0.87 \%$ yielded by the $\mathrm{HCl}$ catalyst (Mansur et al., 2017). The findings of Kim et al. (2015) and Mansur et al. (2017) suggest that microalgae species and process conditions influence the selection of catalysts for transesterification. The effect of nitric acid $\left(\mathrm{HNO}_{3}\right)$ has also been evaluated for the transesterification of microalgae lipid to biodiesel by Park et al. (2017). 


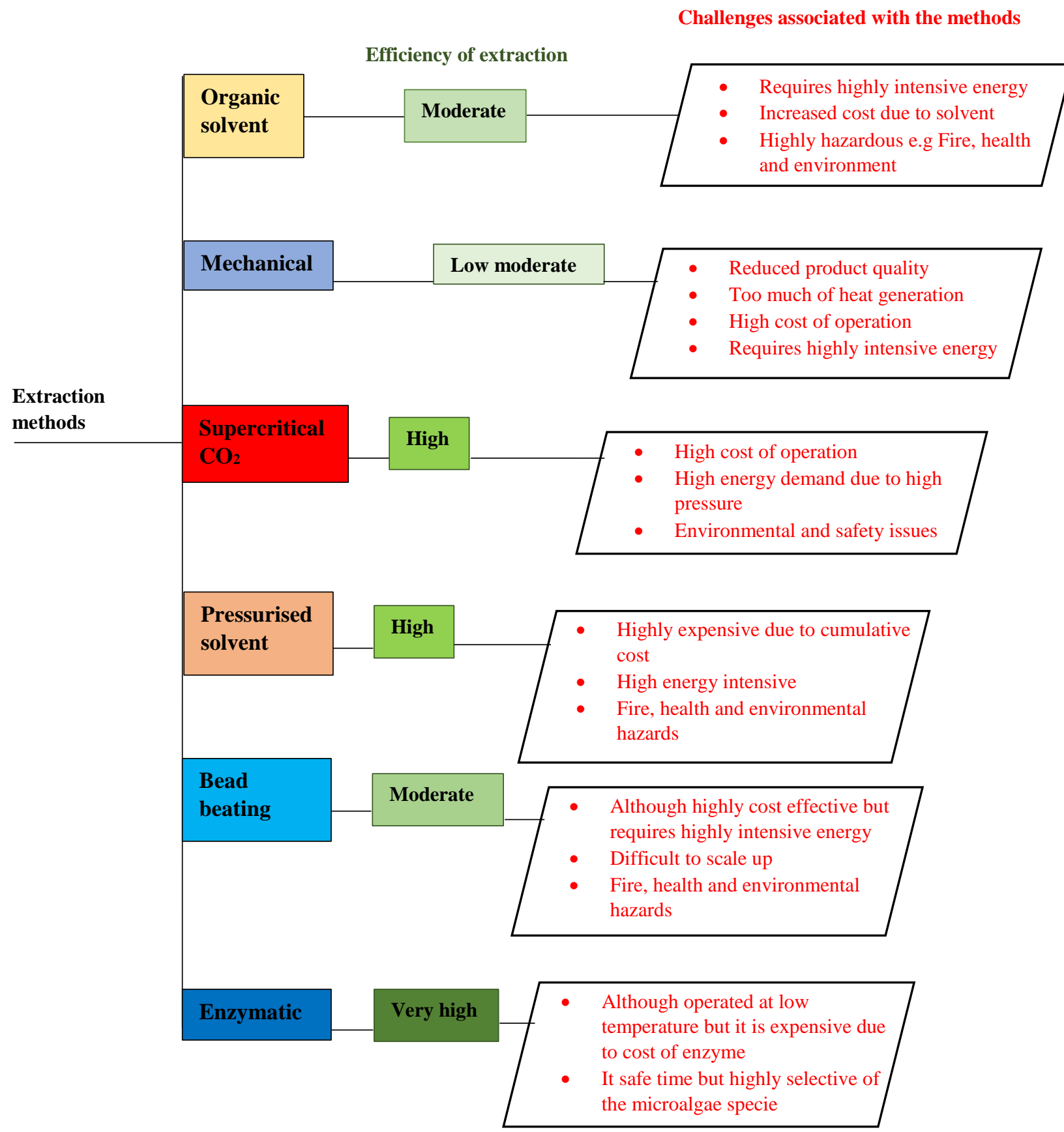

Figure 5: Methods of lipid extraction, efficiency and associated challenges of microalgae.

It was discovered that the $\mathrm{HNO}_{3}$ is not suitable as a catalyst for wet in-situ transesterification of microalgae due to the formation of the shorter chains of fatty acid ethyl esters that is not in the range of biodiesel. Soares et al. (2019) utilised phosphoric acid $\left(\mathrm{H}_{3} \mathrm{PO}_{4}\right)$ as a catalyst for the transesterification of dry biomass of Choricystis minor var. minor and obtained 50\% conversion of triglyceride into biodiesel. These indicate the applicability of homogeneous acid catalysts for the conversion of microalgae lipid to biodiesel, However, there are several difficulties associated with its use. The acid catalysts are not reliable due to much slower reaction rates, difficult temperature requirements, high reactants (oil to alcohol) ratios, concentrations of catalysts, increasing cost due to longer reaction time, higher temperature and pressure as well as severe corrosion problems (Galadima \& Muraza, 2014). Although, Surendhiran \& Vijay (2012) have reported that the homogeneous acid catalysts are highly effective for the transesterification of microalgae lipid with a high free fatty acid (FFA) content, the reaction remains very slow compared to homogeneous base catalyst.

Homogeneous base catalyst has been reported for the transesterification of microalgae lipid of some species such as 
Table 6: Homogeneous catalysts for microalgae species to produce biodiesel.

\begin{tabular}{|c|c|c|c|c|}
\hline Microalgae & Catalyst & Conditions & $\%$ Yield of biodiesel & References \\
\hline Coelastrella sp. & $\mathrm{HCl}$ & $\begin{array}{l}60^{\circ} \mathrm{C}, 1 \mathrm{~h}, 5 \% \text { catalyst loading, methanol: } \\
\text { acetone } 2: 3 \mathrm{v} / \mathrm{v}\end{array}$ & 86.5 & Mansur et al. (2017) \\
\hline Coelastrella sp. & $\mathrm{H}_{2} \mathrm{SO}_{4}$ & $\begin{array}{l}60^{\circ} \mathrm{C}, 1 \mathrm{~h}, 5 \% \text { catalyst loading, methanol: } \\
\text { acetone } 2: 3 \mathrm{v} / \mathrm{v}\end{array}$ & 74.5 & \\
\hline $\begin{array}{l}\text { Trichosporonoleaginosu } \\
s\end{array}$ & $\mathrm{NaOH}$ & $\begin{array}{l}1 \% \mathrm{w} / \mathrm{w} \mathrm{NaOH}, \text { methanol/lipids molar ratio } \\
60: 1,2 \mathrm{~h}, 60^{\circ} \mathrm{C}\end{array}$ & 92.1 & Zhang et al. (2014) \\
\hline Scenedesmus $s p$ & $\mathrm{KOH}$ & $2 \% \mathrm{KOH}, 12: 1$ methanol to oil, $65^{\circ} \mathrm{C}, 30 \mathrm{~min}$ & 91.6 & Chen et al. (2011) \\
\hline
\end{tabular}

Spirogyras and Oedigonium with a high biodiesel yield of 90\% (Milano et al., 2016). Zhang et al. (2014) have documented research on in-situ transesterification of microbial lipids in the presence of $\mathrm{NaOH}$ as a base catalyst. The biodiesel yield of $92.1 \%$ was obtained at $1 \% \mathrm{w} / \mathrm{w} \mathrm{NaOH}$, 360:1 methanol to oil ratio and reaction time of $12 \mathrm{~h}$. Sodium hydroxide $(\mathrm{NaOH})$ may be considered to be highly reactive compared to other homogeneous base catalysts. Chen et al. (2012) investigated the effectiveness of $\mathrm{NaOH}, \mathrm{KOH}$ and $\mathrm{KOCH}_{3}$ towards transesterification of microalgae lipids in a comparative study.

The result showed that the $\mathrm{KOH}$ gave the highest biodiesel yield of $91.6 \%$ followed by $\mathrm{NaOH}(88.3 \%)$ and $\mathrm{KOCH}_{3}$ $(87.6 \%)$. These catalysts have been effective in the transesterification of microalgae lipids. However, the effectiveness of each catalyst on biodiesel yield may vary based on the species of the microalgae. Farooq et al. (2013) have reported the transesterification of lipids extracted from different species of microalgae for biodiesel production. The reaction was performed using $\mathrm{NaOCH}_{3}$ as the catalyst and the yield of biodiesel from different species were reported as $C$. vulgaris (95\%), $R$. hieroglyphicum (91\%), and mixed microalgae culture (92\%). Although the base catalysts have been used for the transesterification of microalgae lipids to biodiesel, they are associated with some difficulties. The use of alkaline catalyst causes the formation of soap which is an undesirable by-product, due to the presence of high FFA and moisture content in the lipid of some species of microalgae (Milano et al., 2016). They are only efficient in the transesterification of microalgae lipids with a low amount of FFA (Umdu et al., 2009).

These homogeneous catalysts (acid and base) are, however, associated with great numbers of complications working against their continuous application (Galadima \& Muraza, 2014). They are very expensive, as such their high cost has hindered the commercialisation of biodiesel from microalgae and even other feedstocks (Singh et al., 2020). Also, challenges like reusability and ease of separation remain drawbacks with the use of homogeneous catalysts as well as high energy requirements and high pollution of the environment ( $\mathrm{Du}$ et al., 2018). To overcome these complications with the use of the homogeneous catalyst for biodiesel production from microalgae lipids, heterogeneous catalysts have been identified.

Heterogeneous (solid) catalysts are environment-friendly, cheap, easily recoverable and reuse, easy of separation, no emulsification and soap production challenges associated with homogeneous catalysts. They are suitable for high FFA feedstock including that of microalgae species in simultaneous esterification and transesterification reaction using a one-pot process to produce biodiesel. Other advantages are the elimination of the washing stage, easy reactivation, corrosion-free and improved product purity (Ajala et al., 2020a). Table 7 presents various microalgae species that were catalysed by different types of heterogeneous catalysts for biodiesel production. The table showed that the catalysts yielded $>90 \%$ of biodiesel in most cases reported, which indicates the suitability of heterogeneous catalysts for microalgae lipids conversion to biodiesel. Carrero et al. (2015) reported the synthesis of FAME from Nannochloropsis gaditana using ion-exchange resins, KSF clay, and silica-alumina as a solid acid catalyst. The ion exchange resins catalyst showed the highest catalytic activity with the biodiesel yield above $90 \pm 0.8 \mathrm{~mol} \%$ followed by KSF clay with a yield of $67 \pm 0.7 \mathrm{~mol} \%$.

The high yield of biodiesel by using ion-exchange resins results from the large pore diameter and higher acidic strength exhibited by protonic resins. Hara (2010) reported that in biodiesel production, improved catalysis by solid acid catalyst may not be wholly based on the acid strength or surface area. The reason is that some solid acid catalysts can possess higher surface area and acid strength and still exhibit lower biodiesel yield. A single-step esterification was executed by Bala et al. (2014) through the deployment of a mesoporous solid acid catalyst known as 35\% phosphotungstic acid loaded KIT-5 catalyst for biodiesel production from microalgae lipid and obtained a yield of $98 \%$. Also, catalyst recycling and regeneration was performed and was shown to be effective with $84 \%$ biodiesel yield even after four cycles of reaction. It was concluded that the catalyst, $35 \%$ phosphotungstic acid loaded KIT-5 possesses the good qualities of a solid acid catalyst such as an interconnected orientation for the large pore to minimize diffusion disputes and high acidic concentration to secure an acceptable reaction rate.

$\mathrm{Li}$ et al. (2011) reported one-step production of biodiesel from Nannochloropsiss using a solid base $\mathrm{Mg}-\mathrm{Zr}$ catalyst. The catalyst was prepared by co-precipitation method by mixing magnesium nitrate hexahydrate and zirconium nitrate pentahydrate in a mass ratio of 2:1. A biodiesel yield of $28 \%$ was obtained when the one-step transesterification method was employed. It was further stated that the solid base $\mathrm{Mg}-\mathrm{Zr}$ catalyst was very effective in the one-step transesterification method as opposed to the conventional two steps with a yield of $22 \%$. Xu et al. (2015) also reported the production of biodiesel from microalgae lipids using $\mathrm{Mg}$-Fe layered double hydroxides (hydrotalcite).

Contrary to the report of $\mathrm{Li}$ et al. (2011), a 3 molar ratio of $\mathrm{Mg}$-Fe catalyst was found to be highly efficient to yield $88 \%$ biodiesel due to its strong basicity and high crystallinity. 
Table 7: Heterogeneous catalysts for biodiesel production using microalgae species.

\begin{tabular}{|c|c|c|c|c|}
\hline Microalgae species & Catalysts & Process parameters & $\begin{array}{c}\text { \% Yield of } \\
\text { biodiesel }\end{array}$ & References \\
\hline Nannochloropsis sp. & $\mathrm{Mg}-\mathrm{Zr}$ (mass ratio of 2) & $\begin{array}{l}10 \% \text { catalyst, } 65^{\circ} \mathrm{C}, 4 \mathrm{~h}, 45 \mathrm{~mL} \\
\text { (methanol/methylene dichloride }=2: 1 \\
(\mathrm{v} / \mathrm{v})\end{array}$ & 22 & Li et al. (2011) \\
\hline Chlorella sp. & $\begin{array}{l}\text { Mg-Fe (hydrotalcite) (mass ratio } \\
\text { of } 3\end{array}$ & $1.5 \mathrm{~h}$, methanol: oil molar ratio $6: 1,60^{\circ} \mathrm{C}$. & 88 & Xu et al. (2015) \\
\hline Chlorella sp. & $\begin{array}{l}\mathrm{Mg}-\mathrm{Al} \text { mass } \\
\text { (hydrotalcite) }\end{array}$ & $\begin{array}{l}\text { Methanol: oil molar ratio } 6.4: 1 \text {, catalyst } \\
\text { amount } 1.7 \mathrm{wt} \%, 66^{\circ} \mathrm{C}\end{array}$ & 90.3 & Zeng et al. (2014) \\
\hline Chlorella pyrenoidosa & Sulfonated Graphene oxide & $40 \mathrm{~min}, 5 \%$ wt catalyst, $90^{\circ} \mathrm{C}$. & 95.1 & Cheng et al. (2016) \\
\hline $\begin{array}{l}\text { Lipid Extracted from a } \\
\text { microalgae specie }\end{array}$ & $\mathrm{Li}_{4} \mathrm{SiO}_{4}$ & $\begin{array}{l}3 \% \text { wt catalyst, } 68^{\circ} \mathrm{C} \text {, methanol: oil molar } \\
\text { ratio } 18: 1,4 \mathrm{~h} .\end{array}$ & 76.2 & Dai et al. (2014) \\
\hline
\end{tabular}

Moreover, the catalyst showed to be highly reusable even after the fourth use, although its catalytic activities decrease after biodiesel from microalgae lipids using $\mathrm{Mg}$-Fe layered double hydroxides (hydrotalcite).

Contrary to the report of $\mathrm{Li}$ et al. (2011), a 3 molar ratio of $\mathrm{Mg}-\mathrm{Fe}$ catalyst was found to be highly efficient to yield $88 \%$ biodiesel due to its strong basicity and high crystallinity. Moreover, the catalyst showed to be highly reusable even after the fourth use, although its catalytic activities decrease after each run. An improvement in the biodiesel yield was noticed in the report of Zeng et al. (2014) when a 4 molar ratio of $\mathrm{Mg}$ Al hydrotalcite was used. Dahdah et al. (2018) also stated that the difference in the activity of the hydrotalcite is attributed to the accessibility of their active phase which majorly depends on the method of their preparation. The use of $\mathrm{Mg}-\mathrm{Al}$ (hydrotalcite) developed by the urea method still poses some drawbacks in terms of recovery and separation from resulting biodiesel products (Xu et al., 2015). Therefore, more research needs to be done to improve the yield of FAMEs from microalgae lipids by considering factors such as the molar ratio of mixed oxides, microalgae properties, temperature, agitation rate and monohydric alcohols. These factors tend to increase the cost of biodiesel production when heterogeneous catalysts are applied as the process usually requires a lot of energy. This is a major barrier to the cost-effectiveness and sustainability of microalgae for biodiesel production. Hence, it has become imperative to use catalysts with less energy requirement such as enzymes to overcome this problem.

The use of enzymes as catalysts for biodiesel production from microalgae lipids is gaining wide acceptance due to its economic feasibility and being environmentally benign which eliminates the adverse effects of chemical catalysts (Hossain et al., 2020). Also, the enzymatic transesterification of triglycerides has a high-purity biodiesel yield, no side reaction, reduced operational cost, easy separation, it is recyclable and has no alkaline wastewater. These advantages indicate that enzymatic transesterification is the most suitable among other catalysts, for sustainable biodiesel production (Hossain et al., 2020; Wang et al., 2014).
Enzymatic catalysis has been found suitable with lesser energy for the transesterification of microalgae lipid with high FFA (Makareviciene \& Skorupskaite, 2019). Enzymes (Lipases) are glycerol ester hydrolases that catalyse transesterification reactions under relatively mild conditions (Villeneuve et al., 2000; Ranganathan et al., 2008). Recently, the transesterification of microalgae oil via enzymatic catalysis is becoming promising as its effectiveness depends on the temperature of the reaction, amount of solvent to be used, oil to alcohol ratio, catalyst loading and time of reaction. Huang et al. (2015) reported the transesterification of microalgae oil using recombinant lipase to achieve either FAME or fatty acid ethyl esters (FAEE) at a maximum biodiesel yield of $>90 \%$ after $24 \mathrm{~h}$. The process of obtaining FAEE was cost-effective, the use of ethanol has a toxic, devastating and damaging effect on the enzymes (Makareviciene \& Skorupskaite, 2019). The authors also discovered that the Thermomyces lanuginous enzyme was the most effective among other commercial lipases considered for the enzymatic transesterification of microalgae lipids in the presence of ethanol.

This suggests that the Thermomyces lanuginous was more stable in the presence of ethanol than other enzymes. Based on the optimisation study using Box Behnken design in Response methodology, 96.9\% of biodiesel yield was achieved at $30^{\circ} \mathrm{C}, 10 \%$ Thermomyces lanuginous lipase, ethanol: oil molar ratio of 3:1 and reaction time of $26 \mathrm{~h}$. It was concluded that the Thermomyces lanuginous lipase remains highly stable for an extended period of 41 cycles which is an important advantage of enzyme over chemical catalysts but, the major drawback in using enzymatic reaction is the longer reaction time. However, Wang et al. (2014) achieved a lower time of $4 \mathrm{~h}$ when Candida sp. (Novozyme 435) enzyme was used for the transesterification of Nannochloropsis oceanica microalgae lipids. The lower reaction time was achieved due to the use of the right solvent (t-butanol) which helped to reduce the effect of phospholipids and glycolipids (fluidity and solubility) in the microalgae lipids. Other enzymes 
employed for the transesterification process of microalgae lipid to produce biodiesel are presented in Table 8 .

Therefore, enzyme catalysts are recommended for the transesterification of microalgae lipids for biodiesel production instead of chemical catalysts, due to the identified advantages. Enzymes for microalgae lipids conversion have a mild reaction condition, low energy consumption, noncorrosive nature and environmental acceptability (He et al., 2018). Worthy of note is that all the catalyst types (homogeneous, heterogeneous and enzymes) successfully produced biodiesel from microalgae. The quality of the biodiesel produced form microalgae compared well with those produced from other generations of feedstocks and fall within the American Standard and Testing Methods (ASTM) as shown in Table 9.

\section{SUSTAINABLE UTILISATION OF MICROALGAE LIPID FOR BIODIESEL PRODUCTION}

Figure 6 is the flowchart of microalgae cultivation to biodiesel production. This describes the process route and conditions at every stage of the process to achieve microalgae as a sustainable feedstock for biodiesel production. Worthy of note is that after lipid extraction from microalgae, its residue and by-products can be converted to various biofuels. Figure 7 shows various routes which can be followed to achieve different biofuels production as obtained from the literature (Medipally et al., 2015; Milano et al., 2016; Brennan \& Owende, 2010). Enhancing the conversion of microalgae to biofuels (power, heat, and fuels) and energy source through various technologies include biochemical/biological conversion, thermochemical conversion, a chemical reaction (transesterification) and direct combustion (power generation) (Peng et al., 2019; Dickinson et al., 2016). The most common way to produce biodiesel is the transesterification process which can be used to convert microalgae lipids to biodiesel. The biodiesel which is also known as FAME is suitable for power compression ignition engines and can replace diesel fuel (Chiaramonti et al., 2015). The transesterification of microalgae has gained a lot of attention recently, due to its sustainability for biodiesel production and could be produced through three protocols, namely:

- two-step protocol which is extraction with organic solvent followed by conversion to biodiesel by a catalyst such as an acid, a base, or an enzyme (Milano et al., 2016),

- direct biodiesel production using an acid catalyst at atmospheric pressure and ambient temperature (Chen et al., 2012),

- one-step conversion to biodiesel at high pressure and high temperature in the absence of a catalyst (Milano et al., 2016).

Each of these protocols has merits and demerits such as the use of high concentrations of sulfuric acid in the case of the direct protocol because the presence of moisture in the biomass limits conversion efficiency. Meanwhile, the presence of moisture content has no significant effect on subcritical or supercritical conditions of the one-step protocol (Chen et al., 2012). However, in the subcritical conditions of the one-step protocol, side reactions occur which produce

Table 8: Enzymes for the transesterification of microalgae oil species for biodiesel production.

\begin{tabular}{|c|c|c|c|c|c|c|}
\hline Microalgae species & Enzymes & Process conditions & Solvent & Acyl Receptor & $\begin{array}{l}\text { \% Yield of } \\
\text { biodiesel }\end{array}$ & References \\
\hline Chlorella vulgaris & Rhizomисоrmiehei & $\begin{array}{l}38^{\circ} \mathrm{C}, 0.2 \% \text { of water (for } \\
\text { methanol), } 0.5 \% \text { (for } \\
\text { ethanol), alcohol to oil molar } \\
\text { ratio } 3: 1 \text { to } 5: 1 \text { (for } \\
\text { methanol) and 5:1 } \\
\text { (for ethanol), alcohol } \\
\text { stepwise addition (two steps } \\
\text { for methanol and four steps } \\
\text { for ethanol), enzyme content } \\
160 \mathrm{U} \text { (methanol), } 560 \mathrm{U} \\
\text { (ethanol), } 24 \mathrm{~h}\end{array}$ & n-Hexane & $\begin{array}{l}\text { Methanol } \\
\text { Ethanol }\end{array}$ & $>90$ & Huang et al. (2015) \\
\hline Chlorella sp. & $\begin{array}{l}\text { Thermomyceslanug } \\
\text { inous }\end{array}$ & $\begin{array}{l}30^{\circ} \mathrm{C}, 10 \% \text { lipase, ethanol: oil } \\
\text { molar ratio of } 3: 1 \text { and } \\
\text { reaction time of } 26 \mathrm{~h} .\end{array}$ & Nil & Ethanol & 96.9 & $\begin{array}{l}\text { Makareviciene et al. } \\
\text { (2017) }\end{array}$ \\
\hline Chlorella sp. & Lipozyme TL IM & $\begin{array}{l}\text { Alcohol to oil molar ratio of } \\
4.5: 1 \text {, } \\
13.3 \% \text { of an enzyme, } 30^{\circ} \mathrm{C} \text {, } \\
13 \mathrm{~h}\end{array}$ & Diesel fuel & Ethanol & 98 & $\begin{array}{l}\text { Makareviciene et al. } \\
\text { (2017) }\end{array}$ \\
\hline Chlorella vulgaris & Candida antarctica & $\begin{array}{l}\text { Methanol to oil molar ratio } \\
12: 1 \text {, oil to } \\
\text { t-butanol ratio } 1: 1(\mathrm{w} / \mathrm{v}) \text {, oil } \\
\text { to lipase } \\
\text { mass ratio } 20: 1(\mathrm{w} / \mathrm{w}), 40^{\circ} \mathrm{C} \text {, } \\
12 \mathrm{~h}, 250 \mathrm{rpm}\end{array}$ & t-Butanol & Methanol & 97 & Xu et al. (2006) \\
\hline $\begin{array}{l}\text { Nannochloropsis } \\
\text { oceqanica IMETI }\end{array}$ & $\begin{array}{l}\text { Candida sp. } \\
\text { Novozyme } 435\end{array}$ & $\begin{array}{l}20 \% \\
\text { of the enzyme, } 25^{\circ} \mathrm{C}, 4 \mathrm{~h} \text {, the } \\
\text { Molar ratio of alcohol to oil } \\
12: 1 .\end{array}$ & t-Butanol & Methanol & 99.1 & Wang et al. (2014) \\
\hline Chlorella sp. & $\begin{array}{l}\text { Candida sp. } \\
\text { Novozyme } 435\end{array}$ & $50 \%$ of lipase, $60^{\circ} \mathrm{C}, 6 \mathrm{~h}$ & $\begin{array}{l}\text { Dimethyl } \\
\text { Carbonate }\end{array}$ & $\begin{array}{l}\text { Dimethyl } \\
\text { Carbonate }\end{array}$ & 75.5 & Du et al. (2018) \\
\hline
\end{tabular}


Table 9: Physicochemical properties of various biodiesel from different feedstocks of microalgae and other generation feedstocks.

\begin{tabular}{|c|c|c|c|c|c|c|c|c|c|c|c|c|}
\hline \multicolumn{13}{|c|}{ Physicochemical Properties } \\
\hline $\begin{array}{l}\text { Feedsto } \\
\text { ck }\end{array}$ & $\begin{array}{l}\text { Catal } \\
\text { yst }\end{array}$ & $\begin{array}{l}\text { FAM } \\
\text { E } \\
\text { conte } \\
\text { nt }(\%, \\
\text { min) }\end{array}$ & $\begin{array}{l}\text { Density } \\
\text { at } 15^{\circ} \mathrm{C} \\
(\mathrm{g} / \mathrm{ml})\end{array}$ & $\begin{array}{l}\text { Kinema } \\
\text { tic } \\
\text { viscosit } \\
\text { y at } \\
\mathbf{4 0} \mathrm{C} \\
\left(\mathrm{mm}^{\circ} / \mathrm{s}\right) \\
\end{array}$ & $\begin{array}{l}\text { Flash } \\
\text { point } \\
\left({ }^{\circ} \mathrm{C}\right)\end{array}$ & $\begin{array}{l}\begin{array}{l}\text { Acid } \\
\text { value } \\
\text { (mg }\end{array} \\
\text { KOH/ } \\
\text { g) }\end{array}$ & $\begin{array}{l}\text { Iodine } \\
\text { value } \\
\text { (g. } \mathbf{J}_{2} \mathbf{1 0 0} \\
\left.{ }^{1} \mathbf{g}^{-1}\right)\end{array}$ & $\begin{array}{l}\text { Cetan } \\
\text { e } \\
\text { numb } \\
\text { er } \\
(\text { min })\end{array}$ & $\begin{array}{l}\text { Oxida } \\
\text { tion } \\
\text { stabili } \\
\text { ty at } \\
110^{\circ} \mathrm{c}\end{array}$ & $\begin{array}{l}\text { Sulph } \\
\text { ur } \\
\text { conte } \\
\text { nt } \\
(\mathbf{M g} \\
\left.\mathbf{k g}^{-1}\right) \\
\end{array}$ & $\begin{array}{l}\text { Wat } \\
\text { er } \\
\text { cont } \\
\text { ent } \\
\left(\mathrm{Mg}^{-}\right. \\
\left.\mathrm{kg}^{-1}\right) \\
\end{array}$ & Reference \\
\hline $\begin{array}{l}{ }^{\mathrm{a}} \mathrm{C} . \\
\text { vulgaris }\end{array}$ & $\mathrm{NaOH}$ & - & 0.916 & 5.20 & 145.0 & 0.49 & - & 53.0 & - & - & 0.04 & $\begin{array}{l}\text { Farooq et al. } \\
\text { (2013) }\end{array}$ \\
\hline 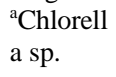 & Lipase & 96.9 & 0.894 & 4.86 & - & 0.28 & 97.12 & 52.0 & 6.76 & 8.100 & 0.25 & $\begin{array}{l}\text { Makareviciene et } \\
\text { al. (2017) }\end{array}$ \\
\hline $\begin{array}{l}\text { aNannoc } \\
\text { hloropsi } \\
\text { s sp. }\end{array}$ & $\mathrm{KOH}$ & 92.2 & 0.854 & 5.67 & - & 0.46 & - & - & 1.93 & - & - & $\begin{array}{l}\text { Makareviciene \& } \\
\text { Skorupskaite } \\
\text { (2019); Chen et al. } \\
\text { (2012) }\end{array}$ \\
\hline $\begin{array}{l}{ }^{\text {a }} \text { Schizoc } \\
\text { hytrium } \\
\text { mangrov } \\
\text { ei PQ6 }\end{array}$ & $\begin{array}{l}\mathrm{HCl} \\
\text { and } \\
\mathrm{CH}_{2} \mathrm{Cl} \\
2\end{array}$ & 88.0 & 0.881 & 5.22 & 186.5 & 7.59 & 46.12 & 68.8 & 0.05 & 0.001 & 0.03 & Hong et al. (2013) \\
\hline $\begin{array}{l}{ }^{\mathrm{a}} \mathrm{R} \text {. } \\
\text { hierogly } \\
\text { phicum }\end{array}$ & $\mathrm{NaOH}$ & - & 0.914 & 5.00 & 146.0 & 0.50 & - & 51.0 & - & - & 0.05 & $\begin{array}{l}\text { Farooq et al. } \\
\text { (2013) }\end{array}$ \\
\hline $\begin{array}{l}\text { a } \\
\text { Scenede } \\
\text { smus sp. }\end{array}$ & $\mathrm{NaOH}$ & 91.0 & 0.852 & 4.15 & - & 0.52 & - & - & 5.42 & 0.020 & 0.04 & Chen et al. (2012) \\
\hline & $\mathrm{KOH}$ & 100.0 & 0.883 & 5.71 & 170.0 & 0.37 & - & 49.0 & - & 0.001 & $\begin{array}{l}<0.0 \\
5\end{array}$ & Ajala et al. (2015) \\
\hline $\begin{array}{l}\text { bPalm } \\
\text { kernel } \\
\text { oil }\end{array}$ & $\mathrm{CaO}$ & 97.09 & 0.868 & 2.49 & 130.0 & - & - & - & - & $<0.05$ & $\begin{array}{l}<0.0 \\
5\end{array}$ & $\begin{array}{l}\text { Ajala et al. } \\
\text { (2020b) }\end{array}$ \\
\hline $\begin{array}{l}{ }^{c} \text { Waste } \\
\text { cooking } \\
\text { oil }\end{array}$ & $\begin{array}{l}\mathrm{Al}- \\
\mathrm{O}=\mathrm{Fe} \\
-\mathrm{O}- \\
\mathrm{Fe}=\mathrm{O} / \\
\mathrm{SO}_{4}\end{array}$ & 99.99 & 0.891 & 3.9 & 130.0 & - & - & 64.34 & - & - & - & $\begin{array}{l}\text { Ajala et al. } \\
\text { (2020a) }\end{array}$ \\
\hline Diesel & - & - & 0.869 & 2.60 & 73.0 & - & - & 49 & - & 0.300 & $\begin{array}{l}<0.0 \\
5\end{array}$ & Ajala et al. (2015) \\
\hline $\begin{array}{l}\text { ASTM } \\
\text { D-6751- } \\
02 \\
\text { Standard } \\
\text { limit }\end{array}$ & - & $>96.5$ & $\begin{array}{l}0.860- \\
0.900\end{array}$ & $1.9-6.0$ & $>130$ & $<0.8$ & $<120$ & $>47$ & $>6$ & $\begin{array}{l}<0.00 \\
5\end{array}$ & $\begin{array}{l}<0.0 \\
5\end{array}$ & $\begin{array}{l}\text { Ajala et al. (2018); } \\
\text { Chen et al. (2012) }\end{array}$ \\
\hline
\end{tabular}

organic acids and heterocyclic nitrogen compounds due to the degradation of proteins and carbohydrates (Huang et al., 2011). These by-products contaminate the biodiesel produced by the protocol and lower its quality, thereby interfering with the purification process, thus increasing the cost of energy and processing. In the same way, the two-step protocol is not as economical as oil extraction before conversion to biodiesel, as it increases the time of processing and energy cost. The stability of the lipid extracted by organic solvent or mechanical methods before transesterification is not guaranteed, as the FFA can be as high as $84 \%$ (oil weight).

So, one-step conversion can be seen as a good potential for the production of biodiesel from microalgae lipid (Chen et al., 2012). Hence, to successfully utilise microalgae to produce biodiesel, efforts need to be geared towards the improvement of the one-step process in an In-situ transesterification using suitable catalysts (Milano et al., 2016).

In-situ transesterification of microalgae lipid to biodiesel is gaining extensive attention, as both the lipid extraction and transesterification can be simultaneously carried out in a one-pot process to obtain a high yield, save time and cost. However, the in-situ process has its drawbacks such as excess methanol requirement (100 times more than two-stage), longer reaction time (6 times more than the twostage) and large energy consumption (Ehimen et al., 2010). Furthermore, in the in-situ transesterification, the reaction occurs when lipid gets in contact with methanol. Thus, the reaction becomes difficult due to the presence of a cell wall that separates lipid from methanol, as the lipid is an intercellular product of microalgae. This necessitates the excess use of methanol to weaken/disrupt and penetrate the cell walls to form biodiesel (Zhang et al., 2014). To improve upon these challenges, ultrasonication in-situ transesterification was recommended because its stirring enhances the lipid conversion to biodiesel due to the improvement in mass transfer (Kulkarni et al., 2006). The process also generates microscopic bubbles that collapse and induces violent shock waves that aid proper mixing and increased mass transfer (Zhang et al., 2014). According to 


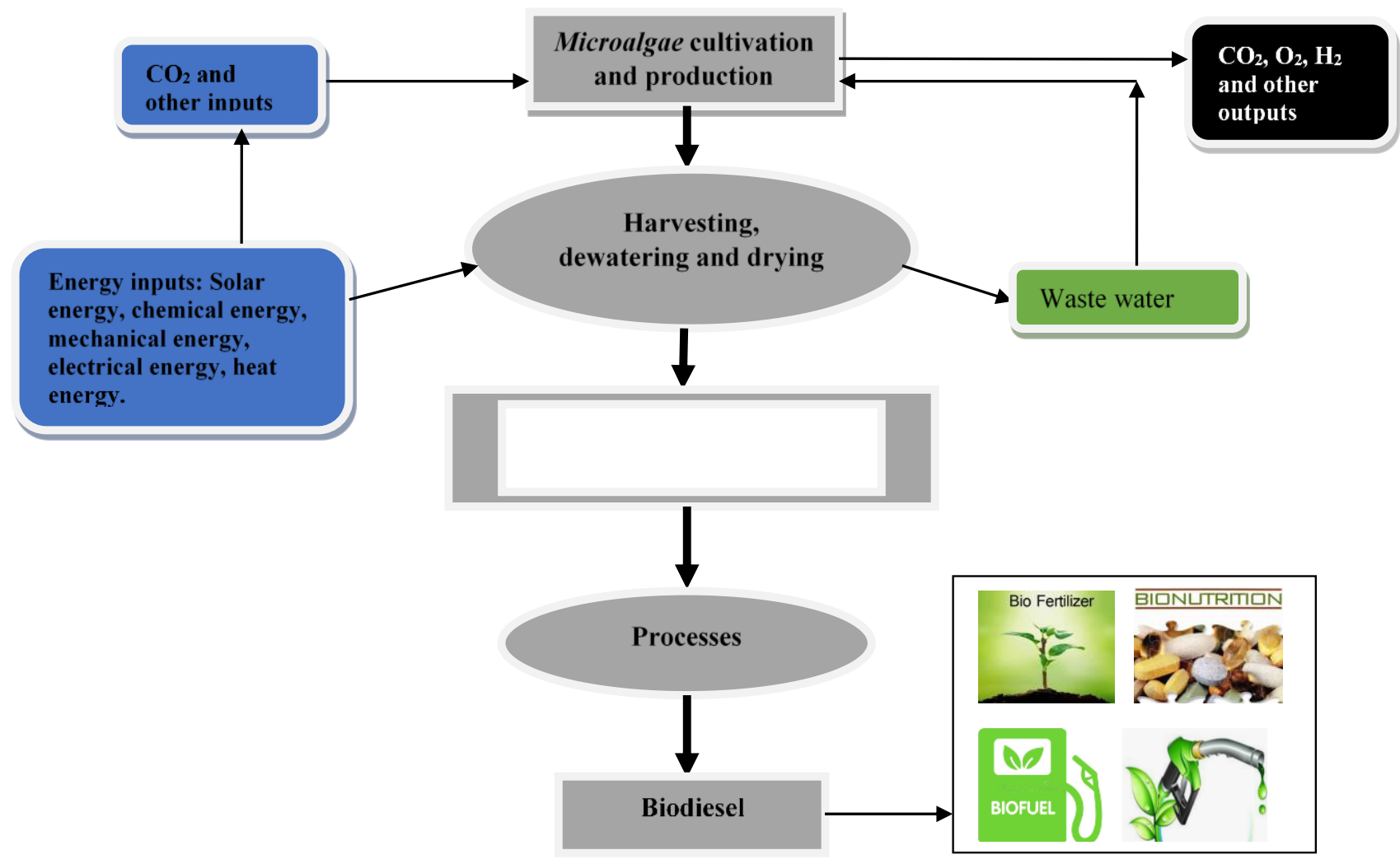

Figure 6: Flowchart of microalgae from cultivation to bioenergy production.

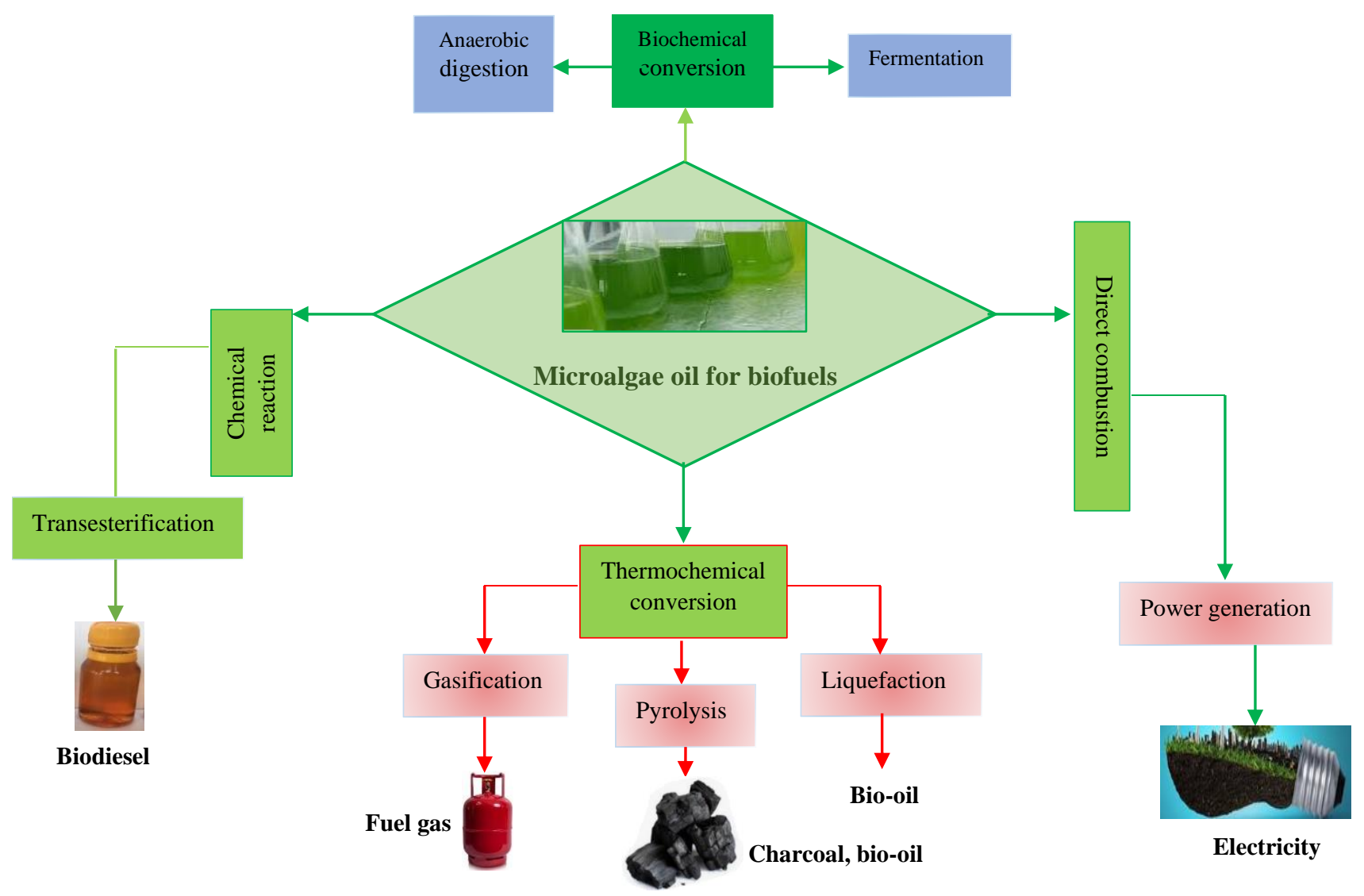

Figure 7: Processes to convert microalgae to various biofuels. 
Zhang et al. (2014), >92.4\% yield of biodiesel was obtained from microalgae lipid at a reaction time of $20 \mathrm{~min}, 5 \% \mathrm{NaOH}$ catalyst and methanol: lipid molar ratio of $60: 1$ by in-situ ultrasonication transesterification process. Whereas $90.4 \%$ yield of biodiesel was obtained at methanol to lipid ratio 360:1 $\mathrm{NaOH}$ addition $5 \% \mathrm{w} / \mathrm{w}$ lipid and 258 reaction time $12 \mathrm{~h}$ by in-situ transesterification process. This suggests that the insitu ultrasonication shows a better performance than the insitu transesterification as the former used less methanol and reaction time. It can be inferred that the in-situ ultrasonication transesterification could be a promising alternative. But, its deployment for commercial biodiesel production has not been ascertained feasible. Therefore, there is an urgent need to develop an economical and environmental-friendly strategy for large-scale microalgae biodiesel production which is an enzyme-based platform (Wang et al., 2014).

The enzymatic transesterification is a promising strategy for microalgae lipid conversion to biodiesel due to their high selectivity and mild operative conditions (Taher et al., 2011). It is a green method that utilises low-energy and highly efficient to produce renewable large-scale biodiesel from microalgal biomass in a cost-effective process ( $\mathrm{He}$ et al., 2018). To effectively utilise the enzyme for the process, the in-situ enzymatic process is recommended.

A novel in-situ ultrasonic-enzymatic process for the extraction and transesterification of microalgae lipid to biodiesel is another technology that can be considered as an alternative route (He et al., 2018). The ultrasound pretreatment method has been reported to be beneficial to transesterification of the lipid. As the low-frequency ultrasonic intensification enhances emulsion generation with alcohols during biodiesel production. Hence, ultrasound in a pre-treatment process can be coupled with enzymatic extraction and enzymatic transesterification concurrently. The process of carrying out both lipid extraction and transesterification in a simultaneous process is known as insitu transesterification (Naveena et al., 2015).

Therefore, the ultrasound-enzymatic extraction and enzymatic transesterification in an in-situ process of using microalgae biomass for biodiesel production would significantly improve the biodiesel yield, economically. This process has not been reported in the literature, however, it would make microalgae a sustainable feedstock for biodiesel production. Figure 8 summarises the protocols recommended in this study for the sustainability of microalgae for biodiesel production.

\section{CONCLUSION AND RECOMMENDATIONS}

Microalgae are considered as promising sustainable feedstocks for biodiesel production, however, its utilisation for commercial production of biodiesel is still pending. This is due to bottlenecks posed by microalgae cultivation, harvesting, lipid extraction and transesterification technique vis-à-vis catalyst type to biodiesel production. This study appraised different approaches to overcome some of these bottlenecks for the sustainability of microalgae for biodiesel production and suggested some recommendations: (1) Species of microalgae rich in lipid with genetic modification should be cultivated, (2) Coagulation/flocculation method

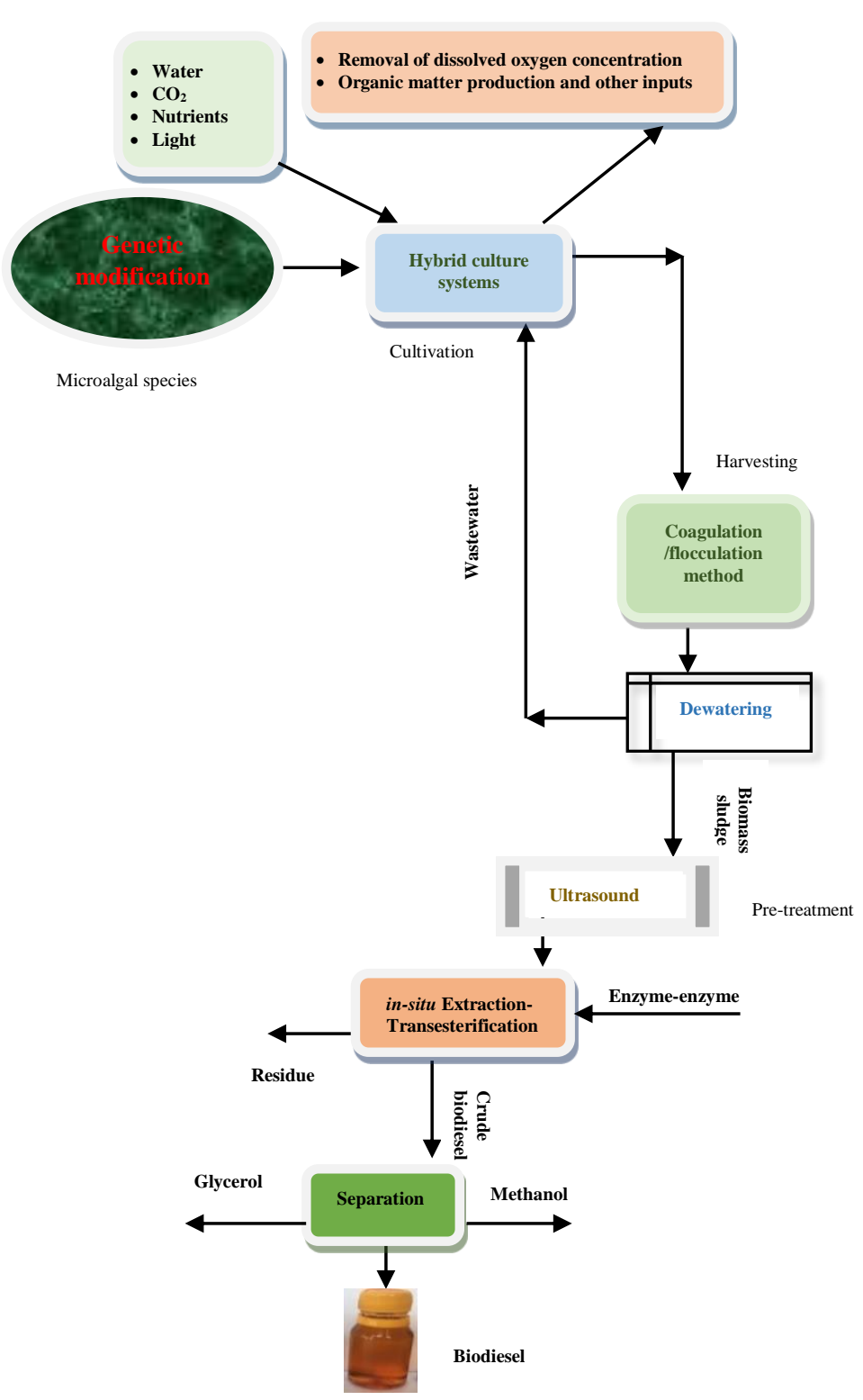

Figure 8: Recommended protocols for the sustainability of microalgae for biodiesel production.

was adjudged a promising and suitable harvesting process of the microalgae biomass, (3) The pre-treatment by ultrasound coupled with enzymatic extraction was suggested as the best due to the numerous advantages, (4) For the transesterification of microalgae lipids to biodiesel, the enzyme catalysed process was the best among others. Therefore, this review suggests a novel integrated ultrasound-enzyme-enzyme insitu pre-treatment-extraction-transesterification design approach to convert microalgae biomass as a sustainable feedstock to biodiesel.

\section{REFERENCES}

Ajala, E. O.; F. Aberuagba, A. M. Olaniyan \& K. R. Onifade. (2015). Comparative study of acid-base and base catalysed process of biodiesel production. Journal of Basic and Applied Research International, 11(2), 87-96. 
Ajala, E. O.; M. A. Ajala, I. K. Ayinla, A. D. Sonusi \& S. E. Fanodun. (2020a). Nano-synthesis of solid acid catalysts from waste-iron-filling for biodiesel production using high free fatty acid waste cooking oil. Scientific Reports, 10(13256), 1-21. https://doi.org/10.1038/s41598020-70025-x

Ajala, E. O.; A. M. Olaniyan, F. Aberuagba, M. A. Ajala, M. M. Odewole. (2018). One-pot synthesis of biodiesel from high FFA shea butter in an optimisation study using response surface methodology. Biofuels, 7269(January).

https://doi.org/10.1080/17597269.2017.1416523

Ajala, E. O.; M. A. Ajala, T. E. Odetoye, F. A. Aderibigbe, O. H. Osanyinpeju \& M. A. Ayanshola. (2020b). Thermal modification of chicken eggshell as heterogeneous catalyst for palm kernel biodiesel production in an optimization process. Biomass Conversion and Biorefinery, 1-19. https://doi.org/10.1007/s13399-02000636-x

Al hattab, M.; A. Ghaly \& A. Hammoud. (2015). Microalgae Harvesting Methods for Industrial Production of Biodiesel: Critical review and comparative analysis fundamentals of renewable energy and applications. Journal of Fundamentals of Renewable Energy and Applications, 5(2), 1-26. https://doi.org/10.4172/20904541.1000154

Alfarisi, M. S. (2020). Sustainable bioethanol production from microalgae through ionic liquid as a potential catalyst: Review. AIP Conference Proceedings, 2223(April). https://doi.org/10.1063/5.0000952

Atafar, Z.; A. Mesdaghinia, J. Nouri, M. Homaee, M. Yunesian \& M. Ahmadimoghaddam. (2010). Effect of fertilizer application on soil heavy metal concentration. Environmental Monitoring Assessment, 160, 83-89.

Bala, D. D.; M. Misra \& D. Chidambaram. (2014). Single step esterification of algae oil using mesoporous solid acid catalyst. Fuel, 117(PARTB), 1093-1095. https://doi.org/10.1016/j.fuel.2013.10.031

Bhatt, N. C.; A. Panwar, T. S. Bisht \& S. Tamta. (2014). Coupling of algal biofuel production with wastewater. The Scientific World Journal, 2014, 1-10.

Branyikova, I.; G. Prochazkova, T. Potocar, Z. Jezkova \& T. Branyik. (2018). Harvesting of Microalgae by Flocculation. Fermentation 4(93), 1-12. https://doi.org/10.3390/fermentation4040093

Brennan, L., \& Owende, P. (2010). Biofuels from microalgae-A review of technologies for production, processing, and extractions of biofuels and co-products. Renewable and Sustainable Energy Reviews, 14(2), 557-577. https://doi.org/10.1016/j.rser.2009.10.009

Carrero, A.; G. Vicente, R. Rodríguez, G. L. Peso, \& C. Santos. (2015). Synthesis of fatty acids methyl esters (FAMEs) from Nannochloropsis gaditana microalga using heterogeneous acid catalysts. Biochemical Engineering Journal, 97, 119-124. https://doi.org/10.1016/j.bej.2015.02.003

Chen, C. Y.; K. L. Yeh, R. Aisyah, D. J. Lee \& J. S. Chang. (2011). Cultivation, photobioreactor design and harvesting of microalgae for biodiesel production: A critical review. Bioresoures Technology, 102(1), 71-81. https://doi.org/https ://doi.org/10.1016/j.biort ech.2010.06.159.

Chen, L.; T. Liu, W. Zhang, X. Chen \& J. Wang. (2012). Biodiesel production from algae oil high in free fatty acids by two-step catalytic conversion. Bioresource Technology, 111, 208-214.

https://doi.org/10.1016/j.biortech.2012.02.033

Chen, Q.; D. Liu, C. Wu, A. Xu \& W. Xia. (2017). Influence of a facile pre-treatment process on lipid extraction from Nannochloropsis sp. through an enzymatic hydrolysis reaction. Royal Society of Chemistry Advances, 7, 5327053277. https://doi.org/10.1039/c7ra11483d

Cheng, J.; Y. Qiu, R. Huang, W. Yang, J. Zhou \& K. Cen. (2016). Biodiesel production from wet microalgae by using graphene oxide as solid acid catalyst. Bioresource Technology, 221, 344-349.

https://doi.org/10.1016/j.biortech.2016.09.064

Chiaramonti, D.; M. Prussi, M. Buffi, D. Casini \& A. Maria. (2015). Thermochemical conversion of microalgae: challenges and opportunities. Energy Procedia, 75, 819-826. https://doi.org/10.1016/j.egypro.2015.07.142

Cho, S.; W. Choi, S. Oh, C. Lee, Y. Seo, J. Kim, C. Song, G. Kim, S. Lee, D. Kang \& H. Lee. (2012). Enhancement of lipid extraction from marine microalga, Scenedesmus associated with high-pressure homogenization process. Journal of Biomedicine and Biotechnology, Article ID 359432, 1-6. https://doi.org/10.1155/2012/359432

Correa, D. F.; H. L. Beyer, J. E. Fargione, J. D. Hill, H. P. Possingham, S. R. Thomas-hall \& P. M. Schenk. (2019). Towards the implementation of sustainable biofuel production systems. Renewable and Sustainable Energy Reviews, 107(February), 250-263. https://doi.org/10.1016/j.rser.2019.03.005

Correa, D. F.; Beyer, H. L., Possingham, H. P., Thomas-hall, S. R., \& Schenk, M. (2017). Biodiversity impacts of bioenergy production: Microalgae vs . fi rst generation biofuels. Renewable and Sustainable Energy Reviews, 74(February), 1131-1146. https://doi.org/10.1016/j.rser.2017.02.068

Cruz, Y. R.; Seidl, P. R., Seidl, R., Diaz, G. C., Diaz, C., Carliz, R. G., Carliz, G., Fortes, M., \& Paula, R. C. V. De. (2018). Cultivation systems of microalgae for the production of biofuels. Intechopen, 200-2918. https://doi.org/10.5772/intechopen.74957

Dahdah, E.; S. Aouad, C. Gennequin, J. Estephane, B. Nsouli, A. Aboukaïs, \& E. Abi-Aad. (2018). Glycerol steam reforming over Ru-Mg-Al hydrotalcite-derived mixed oxides: Role of the preparation method in catalytic activity. International Journal of Hydrogen Energy, 43(43), 1986419872. https://doi.org/10.1016/j.ijhydene.2018.09.042

Dai, Y. M.; K. T. Chen \& C. C. Chen. (2014). Study of the microwave lipid extraction from microalgae for biodiesel production. Chemical Engineering Journal, 250, 267-273. https://doi.org/10.1016/j.cej.2014.04.031

Deconinck, N.; K. Muylaert, W. Ivens \& D. Vandamme. (2018). Innovative harvesting processes for microalgae biomass production: A perspective from patent literature. Algal Research, 31(September 2017), 469-477. https://doi.org/10.1016/j.algal.2018.01.016 
Deng, X.; Y. Li \& X. Fei. (2009). Microalgae: A promising feedstock for biodiesel. African Journal of Microbiology Research, 3(13), 1008-1014. http://www.academicjournals.org/ajmr

Dickinson, S.; M. Mientus \& D. Frey. (2016). A review of biodiesel production from microalgae A review of biodiesel production from microalgae. Clean Technologies and Environmental Policy, 19(3), 637-668. https://doi.org/10.1007/s10098-016-1309-6

Du, Y.; J. Gao, W. Kong, L. Zhou, L. Ma, Y. He, Z. Huang \& Y. Jiang. (2018). Enzymatic synthesis of glycerol carbonate using a Lipase immobilized on magnetic organosilica nanoflowers as a catalyst. ACS Omega, 3(6), 6642-6650. https://doi.org/10.1021/acsomega.8b00746

Dvoretsky, D.; S. Dvoretsky, M. Temnov, E. Akulinin \& E. Peshkova. (2016). Enhanced lipid extraction from microalgae Chlorella vulgaris biomass: Experiments, modelling, optimization. Chemical Engineering Transactions, 49, 175-180. https://doi.org/10.3303/CET1649030

Ehimen, E. A.; Z. F. Sun \& C. G. Carrington. (2010). Variables affecting the in situ transesterification of microalgae lipids. Fuel, 89, 677-684.

Enamala, M. K.; S. Enamala, M. Chavali, J. Donepudi, R. Yadavalli, B. Kolapalli, T. V. Aradhyula, J. Velpuri \& C. Kuppam. (2018). Production of biofuels from microalgaeA review on cultivation, harvesting, lipid extraction, and numerous applications of Microalgae. Renewable Sustainable Energy Review, 94, 49-68.

Farooq, A.; U. K. Amin \& Y. Abdullah. (2013). Transesterification of oil extracted from different species of algae for biodiesel production. African Journal of Environmental Science and Technology, 7(6), 358-364. https://doi.org/10.5897/ajest12.167

Fasaei, F.; J. H. Bitter, P. M. Slegers \& A. J. B. van Boxtel. (2018). Techno-economic evaluation of microalgae harvesting and dewatering systems. Algal Research, 31(June 2017), 347-362. https://doi.org/10.1016/j.algal.2017.11.038

Galadima, A. \& Muraza, O. (2014). Biodiesel production from algae by using heterogeneous catalysts: A critical review. Energy 78, 72-83. https://doi.org/10.1016/j.energy.2014.06.018

Geada, P.; V. Vasconcelos, A. Vicente \& B. Fernandes. (2017). Microalgal biomass cultivation. Algal Green Chemistry, 257-284. https://doi.org/10.1016/B978-0-44463784-0.00013-8

González-gonzález, L. M.; S. Astals, S. Pratt, P. D. Jensen \& P. M. Schenk. (2019). Impact of osmotic shock pre-treatment on microalgae lipid extraction and subsequent methane production. Bioresource Technology Reports, 7(April), 100214. https://doi.org/10.1016/j.biteb.2019.100214

Hara, M. (2010). Biomass conversion by a solid acid catalyst. Energy and Environmental Science, 3(5), 601-607. https://doi.org/10.1039/b922917e

He, Y.; T. Wu, X. Wang, B. Chen \& F. Chen. (2018). Cost-effective biodiesel production from wet microalgal biomass by a novel two-step enzymatic process. Bioresource Technology, 268(August), 583-591.

https://doi.org/10.1016/j.biortech.2018.08.038
Hong, D. D.; D. T. N. Mai, L. T. Thom, N. C. Ha, B. D. Lam, L. T. Tam, H. T. L. Anh \& N. T. H. Thu. (2013). Biodiesel production from Vietnam heterotrophic marine microalga Schizochytrium mangrovei PQ6. Journal of Bioscience and Bioengineering, 116(2), 180-185. https://doi.org/10.1016/j.jbiosc.2013.02.002

Hossain, S. M. Z.; S. A. Razzak, A. F. Al-shater, M. Moniruzzaman \& M. M. Hossain. (2020). Recent advances in enzymatic conversion of microalgal lipids into biodiesel. Energy \& Fuels 34(6), 6735-6750. https://dx.doi.org/10.1021/acs.energyfuels.0c01064

Huang, H. J.; X. Z. Yuan, G. M. Zeng, J. Y. Wang, H. Li, C. F. Zhou, X. K. Pei, Q. A. You \& L. A. Chen. (2011). Thermochemical liquefaction characteristics of microalgae in sub- and supercritical ethanol. Fuel Processing Technology, 92, 147-153.

Huang, J.; J. Xia, W. Jiang, Y. Li \& J. Li. (2015). Biodiesel production from microalgae oil catalyzed by a recombinant lipase. Bioresource Technology, 180, 47-53. https://doi.org/10.1016/j.biortech.2014.12.072

Ibrahim, I. U.; M. Idris, I. A. Hussain, M. U. Kaisan, I. Ajunwa \& A. Shitu. (2020). Investigating the effects of pentanol and biodiesel blends on the performance and emission characteristic of compression ignition engine. Nigerian Journal of Technological Development, 17(4), 278285.

Jegan, S.; P. Jegathese \& M. Farid. (2014). Microalgae as a renewable source of energy: A niche opportunity. Journal of Renewable Energy, Article ID 9813285, 1-10. https://doi.org/10.1155/2021/9813285

Kim, B.; H. Im \& J. W. Lee. (2015). In situ transesterification of highly wet microalgae using hydrochloric acid. Bioresource Technology, 185(February), 421-425. https://doi.org/10.1016/j.biortech.2015.02.092

Kim, K. H.; I. S. Choi, H. M. Kim, S. G. Wi \& H. J. Bae. (2014). Bioethanol production from the nutrient stressinduced microalga Chlorella vulgaris by enzymatic hydrolysis and immobilized yeast fermentation. Bioresource Technology, $\quad 153, \quad 47-54$. https://doi.org/10.1016/j.biortech.2013.11.059

Kulkarni, M. G.; A. K. Dalai \& N. N. Bakhshi. (2006). Utilization of green seed canola oil for biodiesel production. Journal of Chemical Technology and Biotechnology, 81, 1886-1893.

Kumar, R. R.; P. H. Rao \& M. Arumugam. (2015). Lipid extraction methods from microalgae: A comprehensive review. Frontiers in Energy Research, 2(January), 1-9. https://doi.org/10.3389/fenrg.2014.00061

Li, Y.; S. Lian, D. Tong, R. Song, W. Yang, Y. Fan, R. Qing \& C. Hu. (2011). One-step production of biodiesel from Nannochloropsis sp. on solid base Mg-Zr catalyst. Applied Energy, 88(10), 3313-3317. https://doi.org/10.1016/j.apenergy.2010.12.057

Makareviciene, V.; M. Gumbyte, V. Skorupskaite \& E. Sendzikiene. (2017). Biodiesel fuel production by enzymatic microalgae oil transesterification with ethanol. Journal of Renewable and Sustainable Energy, 9(2).

https://doi.org/10.1063/1.4978369

Makareviciene, V. \& Skorupskaite, V. (2019). 
Transesterification of microalgae for biodiesel production. In Second and Third Generation of Feedstocks: The Evolution of Biofuels. Elsevier Inc. https://doi.org/10.1016/B978-0-12815162-4.00017-3.

Mansur, D.; M. A. Fitriady, D. Susilaningsih \& S. P. Simanungkalit. (2017). Production of biodiesel from Coelastrella sp. microalgae. AIP Conference Proceedings, 1904. https://doi.org/10.1063/1.5011925.

Mata, T. M.; A. A. Martins \& N. S. Caetano. (2010). Microalgae for biodiesel production and other applications: A review. Renewable and Sustainable Energy Reviews, 14, 217-232.

Mathimani, T. \& Mallick, N. (2020). A comprehensive review on harvesting of microalgae for biodiesel - Key challenges and future directions. Renewable and Sustainable Energy Reviews, 91(August 2017), 1103-1120.

https://doi.org/10.1016/j.rser.2018.04.083

Medipally, S. R.; F. Yusoff, S. Banerjee \& M. Shariff. (2015). Microalgae as sustainable renewable energy feedstock for biofuel production. BioMed Research International, Article ID 519513, 1-13.

http://dx.doi.org/10.1155/2015/519513

Milano, J.; H. C. Ong, H. H. Masjuki, W. T. Chong, M. K. Lam, P. K. Loh \& V. Vellayan. (2016). Microalgae biofuels as an alternative to fossil fuel for power generation. Renewable and Sustainable Energy Reviews, 58, 180-197. https://doi.org/10.1016/j.rser.2015.12.150

Mubarak, M. \& Shaija, A. (2016). Ultrasonication: An effective pre-treatment method for extracting lipid from Salvinia molesta for biodiesel production. Resource-Efficient Technologies, 2(3), 126-132. https://doi.org/10.1016/j.reffit.2016.07.005

Narala, R. R.; S. Garg, K. K. Sharma \& S. R. Thomashall. (2016). Comparison of microalgae cultivation in photobioreactor, open raceway pond, and a two-stage hybrid system. Frontiers in Energy Research, 4(August), 1-10. https://doi.org/10.3389/fenrg.2016.00029

Naveena, B.; P. Armshaw \& J. T. Pembroke. (2015). Ultrasonic intensification as a tool for enhanced microbial biofuel yields. Biotechnology for Biofuels, 8(140), 1-13. https://doi.org/10.1186/s13068-015-0321-0

Pacheco, M. M.; M. Hoeltz, M. S. A. Moraes \& R. C. S. Schneider. (2015). Microalgae: Cultivation techniques and wastewater phycoremediation. Journal of Environmental Science and Health, Part A : Toxic/Hazardous Substances and Environmental Engineering, 50(6), 583-601. https://doi.org/10.1080/10934529.2015.994951

Park, J.; B. Kim, Y. K. Chang \& J. W. Lee. (2017). Wet in situ transesterification of microalgae using ethyl acetate as a co-solvent and reactant. Bioresource Technology, 230, 814. https://doi.org/10.1016/j.biortech.2017.01.027

Patel, A.; F. Mikes \& L. Matsakas. (2018). An overview of current pretreatment methods used to improve lipid extraction from Oleaginous microorganisms. Molecules, 23(1562), 1-22. https://doi.org/10.3390/molecules23071562

Peng, L.; D. Fu, H. Chu, Z. Wang \& H. Qi. (2019). Biofuel production from microalgae: A review. Environmental Chemistry Letters, 0123456789. https://doi.org/10.1007/s10311-019-00939-0
Piasecka, A.; I. Krzemiñska \& J. Tys. (2014). Physical methods of microalgal biomass pretreatment. International Agrophysics, 28, 341-348. https://doi.org/10.2478/intag2014-0024

Prabakaran, P. \& Ravindran, A. D. (2011). A comparative study on effective cell disruption methods for lipid extraction from microalgae. Letters in Applied Microbiology, 53, 150-154. https://doi.org/10.1111/j.1472765X.2011.03082.X

Quinn, J. C. \& Davis, R. (2015). The potentials and challenges of algae based biofuels: A review of the technoeconomic, life cycle, and resource assessment modeling. Bioresource Technology, 184, 444-452.

Radakovits, R.; R. E. Jinkerson, A. Darzins \& M. C. Posewitz. (2010). Genetic engineering of algae for enhanced biofuel production. Eukaryotic Cell, 9(4), 486-501.

Rakesh, S.; S. Poonguzhali \& J. Karuppaiyan. (2017). Cultivation, harvesting and lipid extraction of microalgae for biodiesel production. Trends in Biosciences, 10(31), 64186423.

Ranganathan, S. V.; S. L. Narasimhan \& K. Muthukumar. (2008). An overview of enzymatic production of biodiesel. Bioresource Technology, 99(10), 3975-3981. https://doi.org/10.1016/j.biortech.2007.04.060

Rokicka, M. \& Zieli, M. (2020). Effects of ultrasonic and microwave pretreatment on lipid extraction of microalgae and methane production from the residual extracted biomass. BioEnergy Research, 1-9. https://doi.org/10.1007/s12155020-10202-y

Roy, A. (2017). A review on harvesting and lipid extraction methods for biodiesel production from microalgae. Research and Reviews in Biosciences, 12(3), 134-143.

Shah, J. H.; A. Deokar, K. Patel, K. Panchal \& A. V. Mehta. (2014). A comprehensive overview on various method of harvesting microalgae according to Indian perspective. International Conference on Multidisciplinary Research \& Practice, I(Vii), 313-317.

Show, P. L.; J. S. Tan, S. Y. Lee, K. W. Chew, M. K. Lam, J. W. Lim \& S. Ho. (2020). A review on microalgae cultivation and harvesting, and their biomass extraction processing using ionic liquids. Bioengineered, 1-37. https://doi.org/10.1080/21655979.2020.1711626

Silva, P. A.; M. C. Costa, A. C. Lopes, A. F. Eliezer, R. C. Leitao, R. C. Mota \& A. B. dos Santos. (2014). Comparison of pretreatment methods for total lipids extraction from mixed microalgae. Renewable Energy, 63, 762-766. https://doi.org/10.1016/j.renene.2013.10.038

Singh, G. \& Patidar, S. K. (2018). Microalgae harvesting techniques: A review. Journal of Environmental Management, 217, 499-508. https://doi.org/10.1016/j.jenvman.2018.04.010

Singh, K.; D. Kaloni, S. Gaur, S. Kushwaha \& G. Mathur. (2020). Current research and perspectives on microalgae-derived biodiesel. Biofuels, 11(1), 1-18. https://doi.org/10.1080/17597269.2017.1278932

Slade, R. \& Bauen, A. (2012). Micro-algae cultivation for biofuels: Cost, energy balance, environmental impacts and future prospects. Biomass and Bioenergy Volume, 53(2013), $29-38$. 
Soares, A. T.; E. B. D'Alessandro, R. G. Lopes, R. B. Derner \& N. R. Antoniosi Filho. (2019). Optimization of biodiesel production by in situ transesterification from dry biomass of Choricystis minor var. minor via response surface methodology. Biofuels, $0(0), \quad 1-7$. https://doi.org/10.1080/17597269.2019.1615771

Surendhiran, D. \& Vijay, M. (2012). Microalgal Biodiesel - A Comprehensive Review on the Potential and Alternative Biofuel. Journal of Chemical Sciences, 2(11), 7182.

Surendhiran, D. \& Vijay, M. (2014). Effect of Various Pretreatment for Extracting Intracellular Lipid from Nannochloropsis oculata under Nitrogen Replete and Depleted Conditions. ISRN Chemical Engineering Article ID 536310, 1-9. http://dx.doi.org/10.1155/2014/536310

Taher, H.; S. Al-zuhair, A. H. Al-marzouqi, Y. Haik, \& M. M. Farid. (2011). A review of enzymatic transesterification of microalgal oil-based biodiesel using supercritical technology. Enzyme Research, Article ID 468292, 1-25. https://doi.org/10.4061/2011/468292

Ullah, K.; M. Ahmad, S. Sultana, L. Keat, V. Kumar, A. Zuhairi, M. Zafar \& Z. Ullah. (2014). Experimental analysis of di-functional magnetic oxide catalyst and its performance in the hemp plant biodiesel production. Applied Energy, 113, 660-669. https://doi.org/10.1016/j.apenergy.2013.08.023

Ulusoy, Y. \& Yu, A. (2018). Investigation of performance and emission characteristics of waste cooking oil as biodiesel in a diesel engine. Petroleum Science, 15: 396-404. https://doi.org/10.1007/s12182-018-0225-2

Umdu, E. S.; M. Tuncer \& E. Seker. (2009). Transesterification of Nannochloropsis oculata microalga's lipid to biodiesel on $\mathrm{Al}_{2} \mathrm{O}_{3}$ supported $\mathrm{CaO}$ and $\mathrm{MgO}$ catalysts. Bioresource Technology, 100(11), 2828-2831. https://doi.org/10.1016/j.biortech.2008.12.027

Villeneuve, P.; J. M. Muderhwa, J. Graille \& M. J. Haas. (2000). Customizing lipases for biocatalysis: A survey of chemical, physical and molecular biological approaches. Journal of Molecular Catalysis - B Enzymatic, 9(4-6), 113148. https://doi.org/10.1016/S1381-1177(99)00107-1
Wang, Y.; J. Liu, H. Gerken, C. Zhang, Q. Hu \& Y. Li. (2014). Highly-efficient enzymatic conversion of crude algal oils into biodiesel. Bioresource Technology, 172, 143-149. https://doi.org/10.1016/j.biortech.2014.09.003

Wang, Y. (2013). Microalgae as the third generation biofuel production, usage, challenges and prospects. Thesis submitted to Department of Earth Sciences, Uppsala University, Villavägen 16, SE- 75236 Uppsala, Sweden.

Xu, H.; X. Miao \& Q. Wu. (2006). High quality biodiesel production from a microalga Chlorella protothecoides by heterotrophic growth in fermenters. Journal of Biotechnology, 126(4), 499-507. https://doi.org/10.1016/j.jbiotec.2006.05.002

Xu, S.; H. Y. Zeng, C. R. Cheng, H. Z. Duan, J. Han, P. X. Ding \& G. F. Xiao. (2015). Mg-Fe mixed oxides as solid base catalysts for the transesterification of microalgae oil. RSC Advances, 5(87), 71278-71286. https://doi.org/10.1039/c5ra14144c

Yin, Z.; L. Zhu, S. Li, T. Hu, R. Chu, F. Mo, D. Hu, C. Liu \& B. Li. (2020). A comprehensive review on cultivation and harvesting of microalgae for biodiesel production: Environmental pollution control and future directions. Bioresource Technology, 301, 122804. https://doi.org/10.1016/j.biortech.2020.122804

Yusuff, A. S. \& Owolabi, J. O. (2019). Synthesis and characterization of alumina supported coconut chaff catalyst for biodiesel production from waste frying oil. South African Journal of Chemical Engineering, 30(July), 42-49. https://doi.org/10.1016/j.sajce.2019.09.001

Zeng, H. Y.; S. Xu, M. C. Liao, Z. Q. Zhang \& C. Zhao. (2014). Activation of reconstructed $\mathrm{Mg} / \mathrm{Al}$ hydrotalcites in the transesterification of microalgae oil. Applied Clay Science, 91-92, 16-24. https://doi.org/10.1016/j.clay.2014.02.003

Zhang, X.; S. Yan, R. D. Tyagi, R. Y. Surampalli \& J. R. Valéro. (2014). Ultrasonication aided in-situ transesterification of microbial lipids to biodiesel. Bioresource Technology, 169, 175-180. https://doi.org/10.1016/j.biortech.2014.06.108

Zhu, L.; S. Huo \& L. Qin. (2015). A microalgae-based biodiesel refinery: Sustainability concerns and challenges. International Journal of Green Energy, 12, 595-602. 